\title{
Effect of dairy farming system, herd, season, parity, and days in milk on modeling of the coagulation, curd firming, and syneresis of bovine milk
}

\author{
G. Bittante, C. Cipolat-Gotet, F. Malchiodi, E. Sturaro, F. Tagliapietra, S. Schiavon, and A. Cecchinato ${ }^{1}$ \\ Department of Agronomy, Food, Natural Resources, Animals and Environment (DAFNAE), University of Padova, Viale dell'Università 16, \\ 35020 Legnaro, Italy
}

\begin{abstract}
The objectives of this study were to characterize the variation in curd firmness model parameters obtained from coagulating bovine milk samples, and to investigate the effects of the dairy system, season, individual farm, and factors related to individual cows (days in milk and parity). Individual milk samples (n $=1,264$ ) were collected during the evening milking of 85 farms representing different environments and farming systems in the northeastern Italian Alps. The dairy herds were classified into 4 farming system categories: traditional system with tied animals (29 herds), modern dairy systems with traditional feeding based on hay and compound feed (30 herds), modern dairy system with total mixed ration (TMR) that included silage as a large proportion of the diet (9 herds), and modern dairy system with silage-free TMR (17 herds). Milk samples were analyzed for milk composition and coagulation properties, and parameters were modeled using curd firmness measures $\left(\mathrm{CF}_{\mathrm{t}}\right)$ collected every $15 \mathrm{~s}$ from a lacto-dynamographic analysis of $90 \mathrm{~min}$. When compared with traditional milk coagulation properties (MCP), the curd firming measures showed greater variability and yielded a more accurate description of the milk coagulation process: the model converged for 93.1\% of the milk samples, allowing estimation of $4 \mathrm{CF}_{\mathrm{t}}$ parameters and 2 derived traits [maximum $\mathrm{CF}\left(\mathrm{CF}_{\max }\right)$ and time from rennet addition to $\left.\mathrm{CF}_{\max }\left(\mathrm{t}_{\max }\right)\right]$ for each sample. The milk samples whose $\mathrm{CF}_{\mathrm{t}}$ equations did not converge showed longer rennet coagulation times obtained from the model $\left(\mathrm{RCT}_{\mathrm{eq}}\right)$ and higher somatic cell score, and came from less-productive cows. Among the sources of variation tested for the $\mathrm{CF}_{\mathrm{t}}$ parameters, dairy herd system yielded the greatest differences for the contrast between the traditional farm and the 3 modern farms, with the latter showing earlier coagulation and greater instant syneresis rate constant $\left(\mathrm{k}_{\mathrm{SR}}\right)$. The use of TMR yielded a greater $t_{\max }$ because of a
\end{abstract}

Received September 28, 2014

Accepted December 31, 2014.

${ }^{1}$ Corresponding author: alessio.cecchinato@unipd.it higher instant curd-firming rate constant $\left(\mathrm{k}_{\mathrm{CF}}\right)$. Season of sampling was found to be very important, yielding higher values during winter for all traits except $\mathrm{k}_{\mathrm{CF}}$ and $\mathrm{k}_{\mathrm{SR}}$. All $\mathrm{CF}_{\mathrm{t}}$ traits were affected by individual cow factors. For parity, milk produced by first-lactation cows showed higher $\mathrm{k}_{\mathrm{CF}}$ and $\mathrm{k}_{\mathrm{SR}}$, but delays in achieving $\mathrm{CF}_{\max }$. With respect to stage of lactation, $\mathrm{RCT}_{\mathrm{eq}}$ and potential asymptotic $\mathrm{CF}$ increased during the middle of lactation and stabilized thereafter, whereas the 2 instant rate constants presented the opposite pattern, with the lowest $\left(\mathrm{k}_{\mathrm{CF}}\right)$ and highest $\left(\mathrm{k}_{\mathrm{SR}}\right)$ values occurring in mid lactation. The new challenge offered by prolonging the test interval and individual modeling of milk technological properties allowed us to study the effects of parameters related to the environment and to individual cows. This novel strategy may be useful for investigating the genetic variability of these new coagulation traits.

Key words: dairy system, milk coagulation, curd firming, syneresis, modeling

\section{INTRODUCTION}

To characterize milk coagulation properties (MCP), researchers developed the lacto-dynamographic technique several decades ago. Lacto-dynamography is based on recording the movement of a small loop pendulum immersed in a linearly oscillating sample of coagulating milk, with the degree of movement taken to represent curd firmness (CF). At that time, oscillation of the pendulum was graphed on photographic paper and all measurements were performed manually (Annibaldi et al., 1977; Zannoni and Annibaldi, 1981). Three single-point measures (McMahon and Brown, 1982) were considered to be useful MCP: (1) rennet coagulation time (RCT, min), which is the interval between the addition of rennet to the time at which the baseline begins to widen due to milk gelation; (2) the time interval between RCT and a measured amplitude of oscillation of $20 \mathrm{~mm}$ on the paper $\left(\mathbf{k}_{\mathbf{2 0}}, \mathbf{m i n}\right)$, which represents the curd-firming rate; and (3) the amplitude of oscillation (representing the final $\mathrm{CF}$ ) recorded 30 min after rennet addition $\left(\mathbf{a}_{\mathbf{3 0}}, \mathbf{m m}\right)$. Since these early 
studies, dairy cows have changed in terms of breed proportions, breeding values, productivity, type, and fitness. Furthermore, dairy farms have moved toward larger, more mechanized and intensive operations, in which cows are fed increasingly energy- and nutrientdense diets and new milking systems and milk-storage methods are used. These changes and the worldwide diffusion of the Holstein breed have collectively contributed to delayed milk coagulation and a slower curdfirming process (Bittante et al., 2012). Increases have also been observed in the incidences of so-called noncoagulating samples (NC, samples that do not coagulate within $30 \mathrm{~min}$ from rennet addition and thus cannot yield RCT or $\mathrm{a}_{30}$ values; Ikonen et al., 1999; Cecchinato et al., 2011) and of milk samples that fail to yield $\mathrm{k}_{20}$ measures within $30 \mathrm{~min}$ (Cipolat-Gotet et al., 2012; Cecchinato et al., 2013). The delay in coagulation time has also reduced the time interval available for curd firming, reduced average $a_{30}$ measures, and strongly increased the correlation between RCT and $\mathrm{a}_{30}$ because of the near-linearity of the CF increase soon after gelation. This has made the latter traits meaningless, such that traditional MCP have lost much of their informative value for the industry.

Furthermore, modern computerized instruments can simultaneously evaluate multiple milk samples, perform all measurements automatically, continuously store raw data for many measures per milk sample, and analyze the data to yield the 3 traditional single-point MCP (Bittante et al., 2012). Some researchers have attempted to study the dynamics of milk curdling using different rheometers (Douillard, 1973, 1986; Gervais, 1983; Dejmek, 1987; O'Callaghan and Guinee, 1996), but only limited research has been conducted on mechanical lacto-dynamographs (McMahon et al., 1984). The need to summarize all of the information recorded by modern instruments and identify more flexible and stable parameters (i.e., parameters that are independent of a few point measures and the length of data recording) led Bittante (2011) to model all CF data automatically recorded by computerized lacto-dynamographs (120 to 240 readings per sample during a $30-$ min test, depending on the instrument). He used a 3-parameter model that included (1) $\mathbf{R} \mathbf{C} \mathbf{T}_{\mathbf{e q}}$, which was estimated by the model; (2) the asymptotic potential $\mathrm{CF}$ at infinite time $\left(\mathbf{C F}_{\mathbf{P}}, \mathbf{m m}\right)$; and (3) an instant rate constant of curd firming $\left(\mathbf{k}_{\mathrm{CF}}\right.$, in $\left.\% / \mathrm{min}\right)$ from $\mathrm{RCT}$ to infinite time. These parameters were estimated using all available data points. They were also independent of any specific point on the curve, and could be estimated for final $\mathrm{CF}$ recordings $<20 \mathrm{~mm}$.

To address the increased frequency of NC samples and exploit new information derived from the tendency of many samples to decrease in CF after 30 min (instead of continuously increasing), Bittante et al. (2013b) proposed to prolong the duration of the test and model the instrument output according to a 4-parameter model that additionally included an instant rate constant for syneresis $\left(\mathbf{k}_{\mathbf{S R}}, \% / \mathrm{min}\right)$. This rate is much slower than $\mathrm{k}_{\mathrm{CF}}$ and shows an opposing effect, in that over the long run it tends to lead the CF curve asymptotically toward zero.

The aims of the present study were (1) to test the applicability of the 4-parameter model to a large data set and characterize the distribution properties of the parameters; (2) to quantify and characterize the effects of the dairy farming system, season, and individual farm on the model parameters and shape of the curd firmness modeled on time $\left(\mathbf{C F}_{\mathbf{t}}\right)$ curve; and (3) to quantify and characterize the effects of individual cow-level sources of variation (parity and DIM) on the model parameters and $\mathrm{CF}_{\mathrm{t}}$ curve shape.

\section{MATERIALS AND METHODS}

\section{Dairy Farming Systems, Herds, and Seasons}

The present study is part of the Cowability-Cowplus projects; it was carried out on 85 herds located in Trento Province (northeastern Italian Alps) and enrolled in the milk-recording program of the local Provincial Federation of Breeders (FPA, Trento, Italy). The herds were chosen from 610 farms and selected to represent different environments and dairy farming systems. The farming systems were analyzed and described by Sturaro et al. (2009, 2013), and classified as follows:

(a) Traditional systems (29 herds) consisting of small farms (average cultivated land 18.6 ha, excluding summer highland pasture) with old barns, relatively few (average, 28.2) lactating cows tied and milked in stalls, feeding yearround on the farm's meadow hay $(60.9 \%$ DM daily intake, with a total of $68.3 \%$ represented by forage DM) and commercial compound feed ( $18.3 \%$ of total DM intake) distributed manually or via automated feeders in the stalls; and common summer transhumance to temporary farms on highland pastures when it is common to feed some concentrates.

(b) Modern dairy systems (30 herds) with traditional feeding methods but no TMR. The farms consisted of modern buildings, with, on average, 39.3 lactating cows that are loose housed and fed using the farm's hay $(53.7 \%$ DMI with a total of $62.0 \%$ represented by forage) and com- 
mercial compound feed, which was given partly in the milking parlor and partly in the manger, typically at a greater quantity than that fed by traditional farms ( $30.4 \%$ of total DMI).

(c) Modern dairy systems (9 herds) feeding silagebased TMR and with, on average, 49.4 lactating cows and fed a TMR that included hay $(22.2 \%$ of DMI with a total of $48.1 \%$ represented by forage DM), maize o grass silage (18.8\% of total DMI), imported alfalfa hay ( $16.2 \%$ of total DMI) and concentrates, which were represented by commercial compound feed ( $14.5 \%$ of total DMI) or (more often) by a mix of cereals (especially maize grain; on average $23.2 \%$ of total DMI), protein feed (often soybean meal), and sometimes dry beet pulp and supplements.

(d) Modern dairy systems (17 herds) with silage-free TMR and, on average, 54.2 cows, similar to (c) except that the diet silage was replaced by additional hay (38.5\% of DMI with a total of $52.5 \%$ represented by forage DM) and concentrates, and some water is added in the mixing wagon to increase the moisture of the TMR to about $50 \%$.

The farms were sampled once during a calendar year, taking into account a distribution of herds of the different dairy systems between 2 main seasons: April to September and October to March.

\section{Animals and Milk Sampling}

In total, 1,264 Brown Swiss cows, all registered in the Italian Brown Swiss Herd Book, were sampled (15 cows per herd, with few exceptions, balanced for parity, DIM, and milk yield). Individual milk samples were obtained once during the evening milking, as described in detail by Cipolat-Gotet et al. (2012) and Bittante et al. (2013a). The collection, refrigeration, transportation, and storage of milk samples were standardized with the aim of minimizing differences among herds and dates. After collection, milk samples (without any preservative) were immediately refrigerated at $4^{\circ} \mathrm{C}$. One subsample (50 mL; destined for milk composition analysis) was transported to the Milk Quality Laboratory of the Trento Breeders Association. The second subsample (about 2,000 $\mathrm{mL}$ ) was transferred to the Milk Laboratory of the Department of Agronomy, Food, Natural Resources, Animals and Environment (DAFNAE) at the University of Padova (Legnaro, Padova, Italy). All subsamples were analyzed and processed the following morning, within $20 \mathrm{~h}$ from collection. Information about cows and herds was obtained from the Superbrown Consortium of Trento (Trento, Italy).

\section{Analyses of Milk Composition and Coagulation Ability}

Each of the smaller (50-mL) individual milk subsamples was analyzed for fat, protein, and casein percentages, using a MilkoScan FT6000 (Foss, Hillerød, Denmark). Somatic cell count values were obtained using a Fossomatic FC counter (Foss) and converted to SCS by means of logarithmic transformation, as follows: SCS = $\left(\log _{2} \mathrm{SCC} \div 100,000\right)-3$ (Ali and Shook, 1980). The milk $\mathrm{pH}$ values were obtained using a Crison Basic 25 electrode (Crison, Barcelona, Spain).

Each of the larger (2,000-mL) individual subsamples was measured for MCP using a mechanical lacto-dynamograph (Formagraph, Foss) and used to produce an individual model cheese, as previously described (Cipolat-Gotet et al., 2013; Bittante et al., 2013a, 2014a). In brief, a rack containing 10 cuvettes was prepared. Portions of the milk sub-samples $(10 \mathrm{~mL})$ were heated for $30 \mathrm{~min}$ to $35^{\circ} \mathrm{C}$ and individually mixed with 200 $\mu \mathrm{L}$ of rennet solution (Hansen Standard 215 with 80 $\pm 5 \%$ chymosin and $20 \pm 5 \%$ pepsin; Pacovis Amrein AG, Bern, Switzerland) freshly diluted to $1.2 \%$ (wt/ vol) in distilled water (to yield 0.051 international milk clotting units $/ \mathrm{mL}$ ). The lacto-dynamograph recorded the width $(\mathrm{mm})$ of the oscillatory graph every $15 \mathrm{~s}$ throughout the extended observation period (90 min after rennet addition). Traditional MCP were provided directly by the instrument, including RCT (min), $\mathrm{k}_{20}$ $(\mathrm{min})$ and $\mathrm{a}_{30}(\mathrm{~mm})$.

\section{Modeling CF and Syneresis}

The CF parameters were measured every $15 \mathrm{~s}$ for 90 min, to yield $360 \mathrm{CF}$ values per sample. The prolongation of recording to $90 \mathrm{~min}$ allowed us to test the 4-parameter model described by Bittante et al. (2013b), which is given as follows:

$$
\mathrm{CF}_{\mathrm{t}}=\mathrm{CF}_{\mathrm{P}} \times\left(1-e^{-\mathrm{k}_{\mathrm{CF}} \times(\mathrm{t}-\mathrm{RCT})}\right) \times e^{-\mathrm{k}_{\mathrm{SR}} \times\left(\mathrm{t}-\mathrm{RCT}_{\mathrm{eq}}\right)},
$$

where $\mathrm{CF}_{\mathrm{t}}$ is the $\mathrm{CF}$ at time $\mathrm{t}(\mathrm{mm}) ; \mathrm{CF}_{\mathrm{P}}$ is the asymptotic potential maximum value of $\mathrm{CF}(\mathrm{mm}) ; \mathrm{k}_{\mathrm{CF}}$ is the instant rate constant for curd firming $(\% / \mathrm{min})$; $\mathrm{k}_{\mathrm{SR}}$ is the instant rate constant for curd syneresis (\%/ $\mathrm{min})$; and $\mathrm{RCT}_{\mathrm{eq}}$ is the rennet coagulation time ( $\mathrm{min}$ ). This model uses all available information to estimate the 4 parameters, which are not (unlike traditional $\mathrm{MCP}$ ) single-point measurements. The $\mathrm{CF}_{\mathrm{P}}$ parameter is conceptually independent from the test duration and not intrinsically dependent on RCT (unlike $\mathrm{a}_{30}$ ). The parameter $\mathrm{k}_{\mathrm{CF}}$ is assumed to increase $\mathrm{CF}$ toward the asymptotic value of $\mathrm{CF}_{\mathrm{P}}$, whereas $\mathrm{k}_{\mathrm{SR}}$ is assumed to 
decrease CF toward a null asymptotic value. In the initial phase of the test, the first rate constant prevails over the second, such that $\mathrm{CF}_{\mathrm{t}}$ increases to a point in time $\left(\mathbf{t}_{\text {max }}\right)$ at which the effects of the 2 parameters are equal but opposite in sign; this is when $\mathrm{CF}_{\mathrm{t}}$ attains its maximum level $\left(\mathbf{C F}_{\text {max }}\right)$. Thereafter, $\mathrm{CF}_{\mathrm{t}}$ decreases, tending toward a null value due to the effect of curd syneresis and the corresponding expulsion of whey. The $\mathrm{RCT}_{\text {eq }}$ parameter has the same meaning as the traditional RCT measure but was estimated using all available data. The $360 \mathrm{CF}_{\mathrm{t}}$ point observations available for each sample were fitted with curvilinear regressions using the nonlinear procedure (PROC NLIN) of SAS (SAS Institute Inc., Cary, NC). The parameters of each individual equation were estimated by using the Marquardt iterative method (350 iterations and a $10^{-5}$ level of convergence). In some cases (87 of 1,264 samples; $6.9 \%$ ), the model did not converge; these samples were considered outliers and excluded from the analysis of all equation parameters.

\section{Statistical Analysis}

The data from the milk analyses, traditional MCP, and parameters of the individual $\mathrm{CF}$ equations were edited to exclude values beyond the interval of mean \pm 3.0 standard deviations, and were then analyzed using a linear mixed model using the MIXED procedure of SAS (SAS Institute Inc.), as follows:

$$
\begin{gathered}
\mathrm{y}_{i j k l m n o}=\mu+\text { dairy system } \\
+\operatorname{season}_{j} \\
+\operatorname{herd}_{k}\left(\text { dairy system } \times \text { season }_{i j}+\text { parity }_{l}+\operatorname{DIM}_{m}\right. \\
+ \text { pendulum }_{n}+\mathrm{e}_{i j k l m n o}
\end{gathered}
$$

where $\mathrm{y}_{i j k l m n o}$ is the observed trait (milk yield, composition, traditional coagulation property, or individual $\mathrm{CF}_{\mathrm{t}}$ equation parameter); $\mu$ is the overall mean; dairy system $_{i}$ is the fixed effect of the $i$ th dairy system $(i=$ 1 to 4$)$; season $_{j}$ is the $j$ th season $(j=1$ April to September; $j=2$ October to March); herd ${ }_{k}$ (dairy system $\times$ season $)_{i j}$ is the random effect of the $k$ th herd ( $k=1$ to $85)$ within the $i$ th dairy system and $j$ th season; parity is the fixed effect of the $l$ th parity $(l=1$ to 4 or more lactations); $\mathrm{DIM}_{m}$ (DIM, interval from parturition to milk sampling) is the $m$ th 60 -d class of DIM (6 classes); pendulum $_{n}$ is the fixed effect of the $n$th pendulum (the position of the sample within the lacto-dynamograph rack; $n=1$ to 10 ); and $\mathrm{e}_{i j k l m n o}$ is the residual random error term $\sim \mathrm{N}\left(0, \sigma^{2}\right)$. The significances of the dairy system and season were tested on the error line of the herd within the dairy system and season; those of parity, DIM class, and pendulum were tested on the error line of the residual variance. The effect of pendulum was not included in the model when daily milk yield, milk fat, and milk protein were analyzed.

Orthogonal contrasts were used to compare dairy systems, as follows: (1) traditional versus the 3 modern dairy systems; (2) within modern systems: the 2 using TMR versus that using traditional feeding; and (3) within farms using TMR, those including silage versus those using water to moisturize the ration. The orthogonal contrasts among different parities were calculated as (1) first versus second and more lactations; (2) second versus third and more lactations; and (3) third versus fourth and more lactations. Last, for DIM, the linear, quadratic, and cubic trends of the classes' LSM were tested. Pearson product-moment correlations for the traditional MCP and parameters of the individual $\mathrm{CF}$ equations were computed using the CORR procedure of SAS (SAS Institute Inc.).

\section{RESULTS}

\section{CF Modeling}

Using the 4-parameter $\mathrm{CF}_{\mathrm{t}}$ model described by Bittante et al. (2013b) on CF measures recorded every 15 s during an extended lacto-dynamographic test (90 min, 360 point observations per sample), the procedure converged for $93.1 \%$ of the milk samples, allowing us to estimate the 4 parameters for each milk sample with a coefficient of determination $\left(\mathrm{R}^{2}\right)$ for the resulting curve that was always greater than $99 \%$. For the $6.9 \%$ of milk samples whose $\mathrm{CF}_{\mathrm{t}}$ data points did not converge, we estimated the 4 parameters of their individual equations, but their $\mathrm{R}^{2}$ values were $<99 \%$ and they were characterized by small $k_{C F}$ values and very high $C_{P}$ values. The distribution of $\mathrm{CF}_{\mathrm{P}}$ is given in Figure 1. The graph shows a large, roughly Gaussian distribution for the $\mathrm{CF}_{\mathrm{P}}$ of converged samples, whereas the small group of nonconverging samples was characterized by a very high $\mathrm{CF}_{\mathrm{P}}(>150 \mathrm{~mm})$.

The milk samples whose $\mathrm{CF}_{\mathrm{t}}$ equations did not converge were produced by cows that were less productive; these samples had a similar chemical composition and a greater SCS with respect to nonconverging samples (Table 1). However, their traditional MCP, which were measured directly by the instrument, were noteworthy; most samples had coagulation problems: $7 / 87$ samples did not coagulate within the entire $90 \mathrm{~min}$ of the prolonged test; 43/87 samples coagulated later than 30 min from rennet addition and would have been classified as $\mathrm{NC}$ under the standard 30-min lacto-dynamographic test; and of the $37 / 87$ samples that coagulated within the standard $30 \mathrm{~min}$, most coagulated after $20 \mathrm{~min}$ 


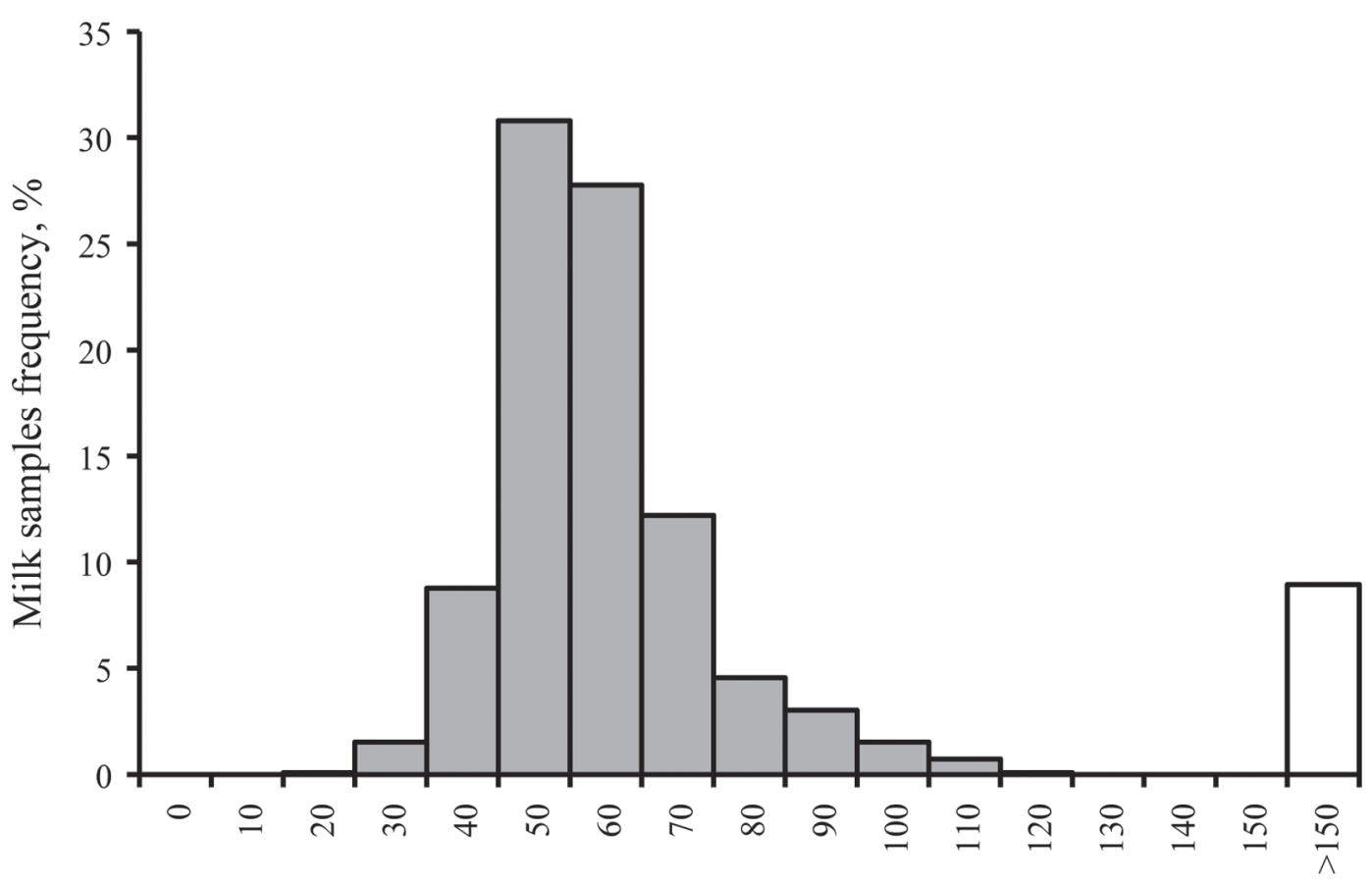

$\mathrm{CF}_{\mathrm{P}}, \mathrm{mm}$

Figure 1. Frequency of milk samples according to the asymptotic potential curd firmness $\left(\mathrm{CF}_{\mathrm{P}}, \mathrm{mm}\right)$ estimates (gray $=$ milk samples with converged equations; white = samples whose equations did not converge).

(late-coagulating samples). The curd-firming process of these samples was very slow and inefficient: $14 / 87$ samples did not reach the 20 -mm oscillation amplitude within the 90 min of the prolonged test, and only a few samples would have reached this threshold within the standard duration of $30 \mathrm{~min}$. In addition, the average of the few $k_{20}$ values available for these samples was more than twice that of the converged samples (Table 1 ). We were able to measure the $a_{30}$ values of only the $37 / 87$ samples that coagulated within $30 \mathrm{~min}$, and their average value $(12.1 \mathrm{~mm})$ was very low (Table 1$)$.

\section{Causes of Variation for Estimated Curd-Firming Parameters}

Table 2 summarizes the results of our statistical analyses regarding milk production, milk quality, coagulation traits, and curd-firming traits. Milk yield was characterized by large differences among the different dairy farming systems and among herds within dairy systems and by a small effect of sampling season. For the individual-level sources of variation (DIM and parity), parity had a large effect and stage of lactation had an even larger effect. For production traits, milk quality (fat and protein contents) was characterized by a smaller effect of dairy system, a halved incidence of herd variability, and high importance of parity and
DIM for protein content and of DIM for fat content. For milk technological traits, the traditional MCP were characterized by very low variabilities among different herds and trivial effects of the farming system and season (with the exception of RCT). For the individuallevel factors, MCP were not affected by parity, but DIM was an important source of variation for all traits. The instrumental source of variation (pendulum) was significant for all traits except RCT. Compared with the traditional MCP, the 4 parameters of the individual $\mathrm{CF}_{\mathrm{t}}$ equations and the 2 derived traits $\left(\mathrm{CF}_{\max }\right.$ and $\left.\mathrm{t}_{\max }\right)$ showed higher herd variability, sensitivity to the farming system, sensitivity to season, and effects of parity, DIM, and pendulum (Table 2).

Major differences were noted between traditional and modern farms (Table 3) in terms of milk production and quality traits (both favoring modern farms). The estimated MCP were similar for traditional and modern dairy farms, whereas analysis of the $\mathrm{CF}_{\mathrm{t}}$ parameters revealed that traditional farms produced milk samples that coagulated earlier and had greater $\mathrm{k}_{\mathrm{SR}}$ values compared with those of modern farms. Because of accelerated syneresis, maximum $\mathrm{CF}$ was lower (but was achieved earlier) for traditional farms compared with modern farms (Table 3). The modern farms that used TMR were characterized by higher milk yields and fat contents than the modern farms that used a more 
Table 1. Descriptive statistics of milk yield, milk quality traits, and traditional milk coagulation properties $(\mathrm{MCP})^{1}$ for samples that reached convergence status and that failed to reach convergence in modeling milk curd firmness

\begin{tabular}{|c|c|c|c|c|c|c|}
\hline \multirow[b]{2}{*}{ Item } & \multicolumn{3}{|c|}{ Convergent samples } & \multicolumn{3}{|c|}{ Nonconvergent samples } \\
\hline & $\begin{array}{c}\text { No. of } \\
\text { samples }\end{array}$ & Mean & $\mathrm{CV}, \%$ & $\begin{array}{c}\text { No. of } \\
\text { samples }\end{array}$ & Mean & $\mathrm{CV}, \%$ \\
\hline $\mathrm{RCT}, \min$ & 1,174 & 19.2 & 26.3 & 80 & 33.7 & 31.4 \\
\hline $\mathrm{k}_{20}, \min$ & 1,161 & 5.2 & 51.9 & 73 & 12.4 & 62.1 \\
\hline Fat, \% & 1,173 & 4.23 & 17.1 & 87 & 4.09 & 17.1 \\
\hline Protein, $\%$ & 1,173 & 3.71 & 11.7 & 87 & 3.87 & 10.5 \\
\hline Casein, \% & 1,173 & 2.88 & 11.4 & 87 & 2.99 & 10.4 \\
\hline Casein number, $\%$ & 1,177 & 0.78 & 5.6 & 87 & 0.77 & 5.4 \\
\hline Lactose, $\%$ & 1,173 & 4.86 & 3.9 & 87 & 4.71 & 6.0 \\
\hline Urea, mg/100 g & 1,172 & 26.0 & 32.0 & 87 & 25.8 & 30.4 \\
\hline $\mathrm{pH}$ & 1,177 & 6.64 & 1.2 & 87 & 6.70 & 1.2 \\
\hline
\end{tabular}

${ }^{1} \mathrm{RCT}=$ rennet coagulation time; $\mathrm{k}_{20}=$ time interval between $\mathrm{RCT}$ and a measured amplitude of oscillation of $20 \mathrm{~mm}$ (i.e., curd-firming rate); $\mathrm{a}_{30}=$ amplitude of oscillation (representing the final curd firmness) recorded 30 min after rennet addition.

traditional strategy of separately supplying different feedstuffs. Regarding the technological properties of the milk, TMR did not affect coagulation, firmness, or syneresis, but did increase the firming rate (measured by both $\mathrm{k}_{20}$ and $\mathrm{k}_{\mathrm{CF}}$ ), thus anticipating the achieving of maximum curd firmness. Results from farms that supplied silage-based TMR were very similar to those from farms that provided TMR based on dry feedstuffs moisturized with water, with the only exception being the association of a greater milk fat content with the former system (Table 3).

When corrected for DIM and calving season, season of sampling (Table 4) was not very important for milk yield, with a slight (but significant) difference in favor of herds sampled during the summer (i.e., April-September). However, season did appear to affect quality

Table 2. Analysis of variance of milk yield, fat and protein contents, traditional milk coagulation properties (MCP), and parameters of individual models of curd firming and syneresis process (CF modeling)

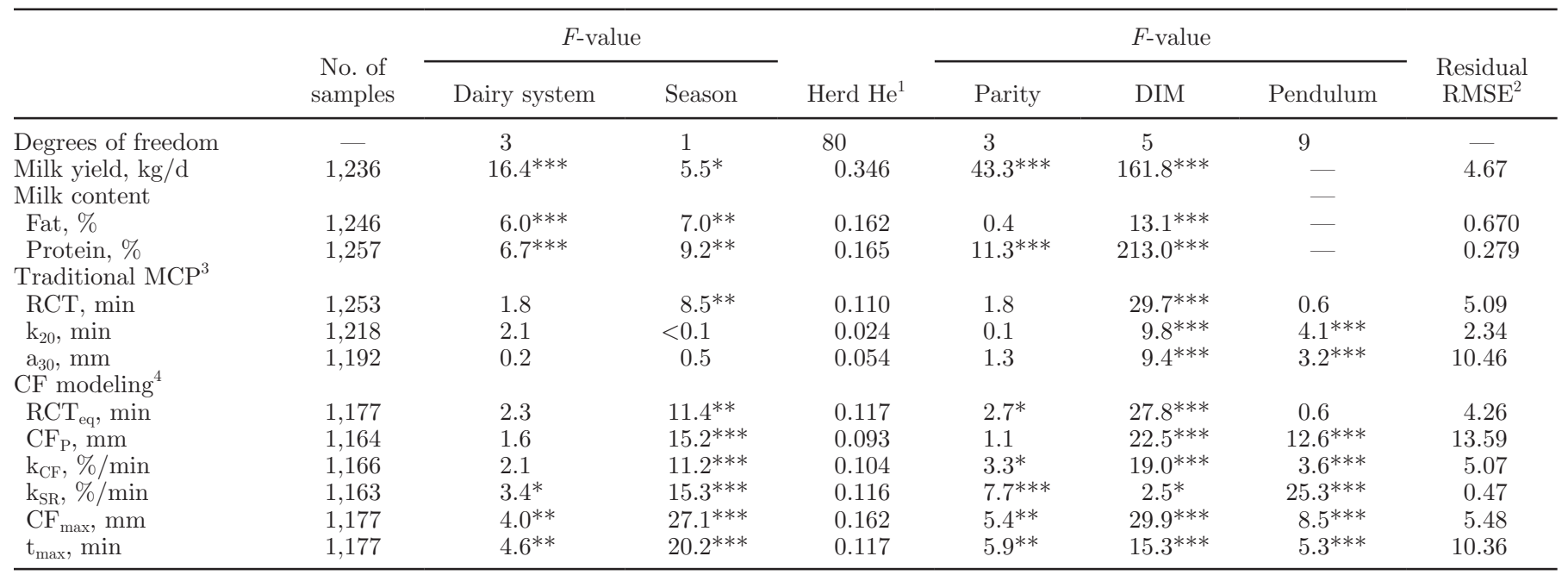

${ }^{1}$ The variance of herd within dairy system and season is expressed as ratio with total variance (herd plus residual).

${ }^{2}$ Root mean square error.

${ }^{3} \mathrm{RCT}=$ rennet coagulation time; $\mathrm{k}_{20}=$ time interval between RCT and a measured amplitude of oscillation of $20 \mathrm{~mm}$ (i.e., curd-firming rate); $\mathrm{a}_{30}=$ amplitude of oscillation (representing the final curd firmness) recorded 30 min after rennet addition.

${ }^{4} \mathrm{RCT}_{\mathrm{eq}}=\mathrm{RCT}$ estimated by $\mathrm{CF}$ model; $\mathrm{CF}_{\mathrm{P}}=$ asymptotic potential $\mathrm{CF}$ at infinite time; $\mathrm{k}_{\mathrm{CF}}=$ instant rate constant of curd firming; $\mathrm{k}_{\mathrm{SR}}=$ instant rate constant for syneresis; $\mathrm{CF}_{\max }=$ maximum curd firmness; $\mathrm{t}_{\max }=$ time to maximum curd firmness.

${ }^{*} P<0.05$; ${ }^{* *} P<0.01$; *** $P<0.001$. 
Table 3. Effects of dairy system and moisture source of TMR on milk yield and quality traits, traditional milk coagulation properties (MCP), and modeling of curd firming and syneresis process ( $\mathrm{CF}$ modeling)

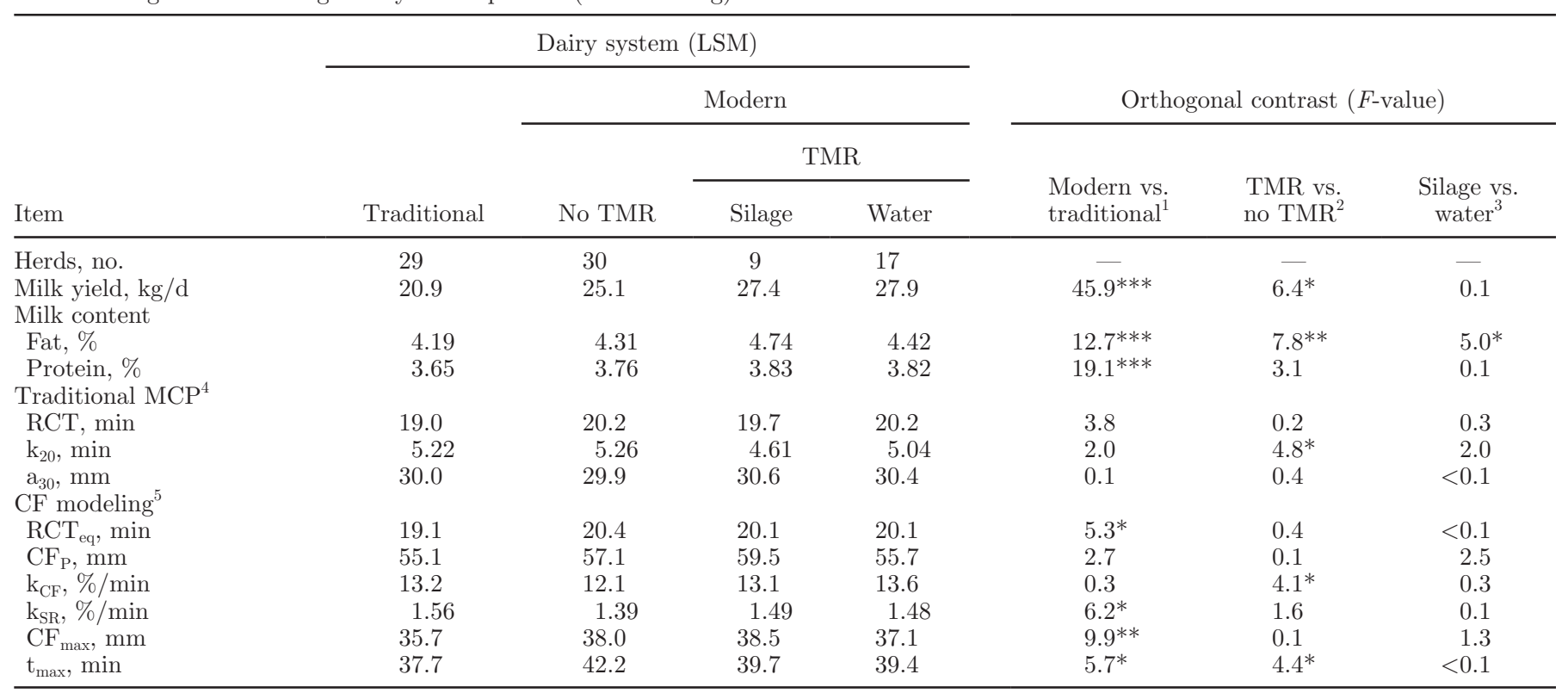

${ }^{1}$ Contrast between the traditional dairy system and the 3 modern systems.

${ }^{2}$ Contrast between the modern-no TMR system and the 2 modern TMR systems.

${ }^{3}$ Contrast between the modern TMR silage system and the modern TMR water system.

${ }^{4} \mathrm{RCT}=$ rennet coagulation time; $\mathrm{k}_{20}=$ time interval between $\mathrm{RCT}$ and a measured amplitude of oscillation of $20 \mathrm{~mm}$ (i.e., curd-firming rate); $\mathrm{a}_{30}=$ amplitude of oscillation (representing the final curd firmness) recorded 30 min after rennet addition.

${ }^{5} \mathrm{RCT}_{\mathrm{eq}}=\mathrm{RCT}$ estimated by $\mathrm{CF}$ model; $\mathrm{CF}_{\mathrm{P}}=$ asymptotic potential $\mathrm{CF}$ at infinite time; $\mathrm{k}_{\mathrm{CF}}=$ instant rate constant of curd firming; $\mathrm{k}_{\mathrm{SR}}=$ instant rate constant for syneresis; $\mathrm{CF}_{\max }=$ maximum curd firmness; $\mathrm{t}_{\max }=$ time to maximum curd firmness.

${ }^{*} P<0.05 ;{ }^{* *} P<0.01 ;{ }^{* * *} P<0.001$.

traits (milk fat and protein contents were greater during the winter) and traditional RCT, which was shorter in summer than in winter. The season of sampling strongly influenced all of the $\mathrm{CF}_{\mathrm{t}}$ models and maximum $\mathrm{CF}$ traits, which were greater during the winter, except for the 2 instant rate constants, which were smaller.

As expected, parity had a very important effect on milk yield (Table 5), particularly when we compared the first lactation with the following lactations. Regarding the effects of parity on milk quality traits, fat was unaffected, while the protein content showed small but significant decreases as the number of lactations increased. The traditional MCP were not affected by parity. With respect to the modeling of $\mathrm{CF}_{t}$, both instant rate constants were affected by parity; the values increased from the first lactation to subsequent lactations, and $\mathrm{k}_{\mathrm{SR}}$ increased from the third lactation to the following lactation. The observed increase of syneresis with an increasing number of lactations was accompanied by a parallel decrease and early maximum CF. As expected, milk yield decreased linearly during lactation (Table 6), as the 2-mo intervals mask the growing phase to peak of lactation. Conversely, milk fat and protein contents increased linearly during lactation. The traditional MCP changed during lactation, with
Table 4. Effects of season on milk yield and quality traits, traditional milk coagulation properties (MCP), and modeling of curd firming and syneresis process (CF modeling)

\begin{tabular}{|c|c|c|}
\hline Item & April-September & October-March \\
\hline Herds, no. & 38 & 47 \\
\hline Milk yield, $\mathrm{kg} / \mathrm{d}$ & $26.2^{\mathrm{a}}$ & $24.4^{\mathrm{b}}$ \\
\hline \multicolumn{3}{|l|}{ Milk content } \\
\hline Fat, \% & $4.31^{\mathrm{A}}$ & $4.52^{\mathrm{B}}$ \\
\hline Protein, $\%$ & $3.71^{\mathrm{A}}$ & $3.81^{\mathrm{B}}$ \\
\hline \multicolumn{3}{|l|}{ Traditional $\mathrm{MCP}^{1}$} \\
\hline RCT, min & $19.0^{\mathrm{A}}$ & $20.5^{\mathrm{B}}$ \\
\hline $\mathrm{k}_{20}, \min$ & 5.02 & 5.04 \\
\hline $\mathrm{a}_{30}, \mathrm{~mm}$ & 29.9 & 30.5 \\
\hline \multicolumn{3}{|l|}{$\mathrm{CF}$ modeling ${ }^{2}$} \\
\hline $\mathrm{RCT}_{\mathrm{eq}}, \min$ & $19.2^{\mathrm{A}}$ & $20.7^{\mathrm{B}}$ \\
\hline $\mathrm{CF}_{\mathrm{P}}, \mathrm{mm}$ & $54.3^{\mathrm{A}}$ & $59.3^{\mathrm{B}}$ \\
\hline $\mathrm{k}_{\mathrm{CF}}, \% / \min$ & $13.8^{\mathrm{B}}$ & $12.2^{\mathrm{A}}$ \\
\hline $\mathrm{k}_{\mathrm{SR}}, \% / \mathrm{min}$ & $1.55^{\mathrm{B}}$ & $1.37^{\mathrm{A}}$ \\
\hline $\mathrm{CF}_{\max }, \mathrm{mm}$ & $35.6^{\mathrm{A}}$ & $39.0^{\mathrm{B}}$ \\
\hline $\mathrm{t}_{\max }, \min$ & $37.4^{\mathrm{A}}$ & $42.1^{\mathrm{B}}$ \\
\hline
\end{tabular}

a,b,A,B Means within a row with different superscripts differ significantly $\left({ }^{\mathrm{a}, \mathrm{b}} P<0.05 ;{ }^{\mathrm{A}, \mathrm{B}} P<0.01\right)$.

${ }^{1} \mathrm{RCT}=$ rennet coagulation time; $\mathrm{k}_{20}=$ time interval between $\mathrm{RCT}$ and a measured amplitude of oscillation of $20 \mathrm{~mm}$ (i.e., curd-firming rate); $a_{30}=$ amplitude of oscillation (representing the final curd firmness) recorded $30 \mathrm{~min}$ after rennet addition.

${ }^{2} \mathrm{RCT}_{\mathrm{eq}}=\mathrm{RCT}$ estimated by $\mathrm{CF}$ model; $\mathrm{CF}_{\mathrm{P}}=$ asymptotic potential $\mathrm{CF}$ at infinite time; $\mathrm{k}_{\mathrm{CF}}=$ instant rate constant of curd firming; $\mathrm{k}_{\mathrm{SR}}=$ instant rate constant for syneresis; $\mathrm{CF}_{\max }=$ maximum curd firmness; $\mathrm{t}_{\max }=$ time to maximum curd firmness. 
Table 5. Effects of the parity of cow on milk yield and quality traits, on traditional milk coagulation properties (MCP), and on modeling of curd firming and syneresis process (CF modeling)

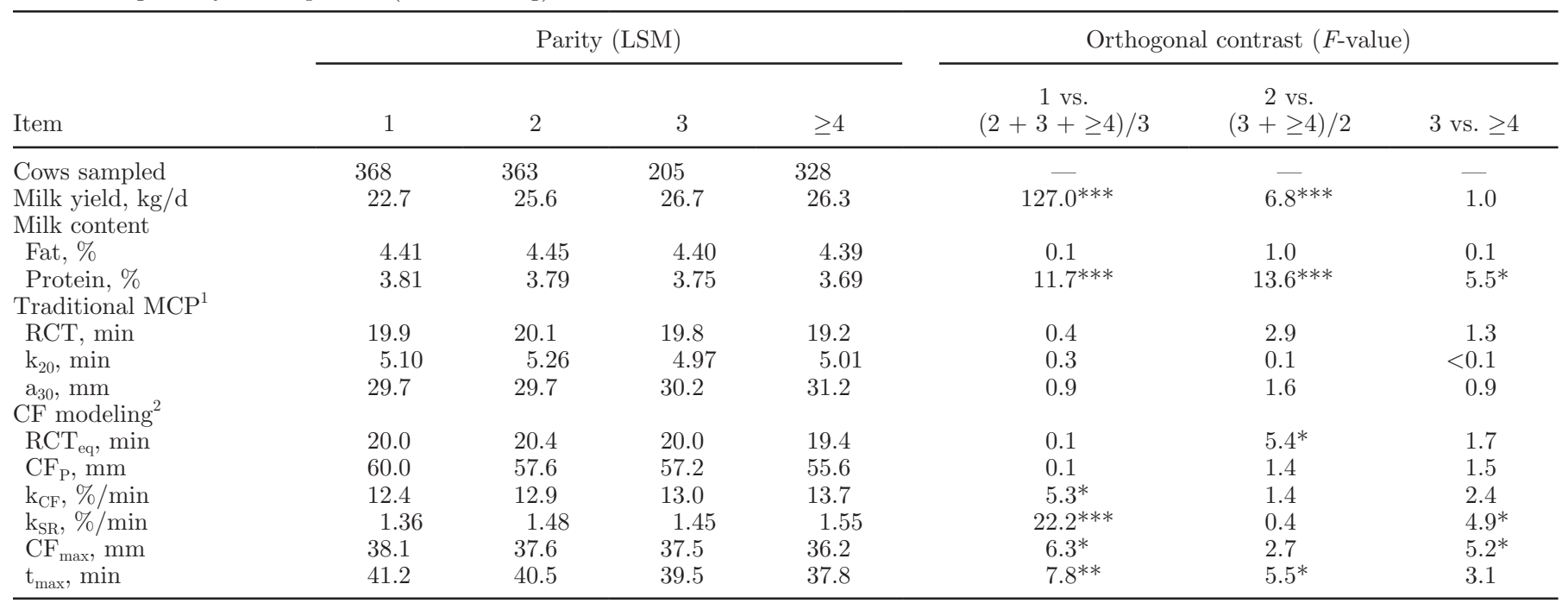

${ }^{1} \mathrm{RCT}=$ rennet coagulation time; $\mathrm{k}_{20}=$ time interval between $\mathrm{RCT}$ and a measured amplitude of oscillation of $20 \mathrm{~mm}$ (i.e., curd-firming rate); $\mathrm{a}_{30}=$ amplitude of oscillation (representing the final curd firmness) recorded 30 min after rennet addition.

${ }^{2} \mathrm{RCT}_{\mathrm{eq}}=\mathrm{RCT}$ estimated by $\mathrm{CF}$ model; $\mathrm{CF}_{\mathrm{P}}=$ asymptotic potential $\mathrm{CF}$ at infinite time; $\mathrm{k}_{\mathrm{CF}}=$ instant rate constant of curd firming; $\mathrm{k}_{\mathrm{SR}}=$ instant rate constant for syneresis; $\mathrm{CF}_{\max }=$ maximum curd firmness; $\mathrm{t}_{\max }=$ time to maximum curd firmness.

${ }^{*} P<0.05 ;{ }^{* *} P<0.01 ;{ }^{* * *} P<0.001$.

coagulation rapidly becoming delayed during the first half of lactation (showing both linear and quadratic trends); this trend worsened until mid lactation, and $\mathrm{k}_{20}$ and $\mathrm{a}_{30}$ values recovered thereafter. Among the $\mathrm{CF}_{\mathrm{t}}$ parameters and derived traits, $\mathrm{RCT}_{\mathrm{eq}}$ and $\mathrm{CF}_{\mathrm{P}}$ increased to mid lactation and stabilized thereafter (showing both linear and quadratic trends; Table 6). In contrast, the 2 instant rate constants showed opposing patterns, yielding their lowest $\left(\mathrm{k}_{\mathrm{CF}}\right)$ and highest $\left(\mathrm{k}_{\mathrm{SR}}\right)$ values at mid lactation. Finally, maximum $\mathrm{CF}$ showed a progressive delay during the first part of lactation and then increased during the second part of lactation.

Table 6. Effects of DIM of the cow on milk yield and quality traits, traditional milk coagulation properties (MCP), and on modeling of curd firming and syneresis process (CF modeling)

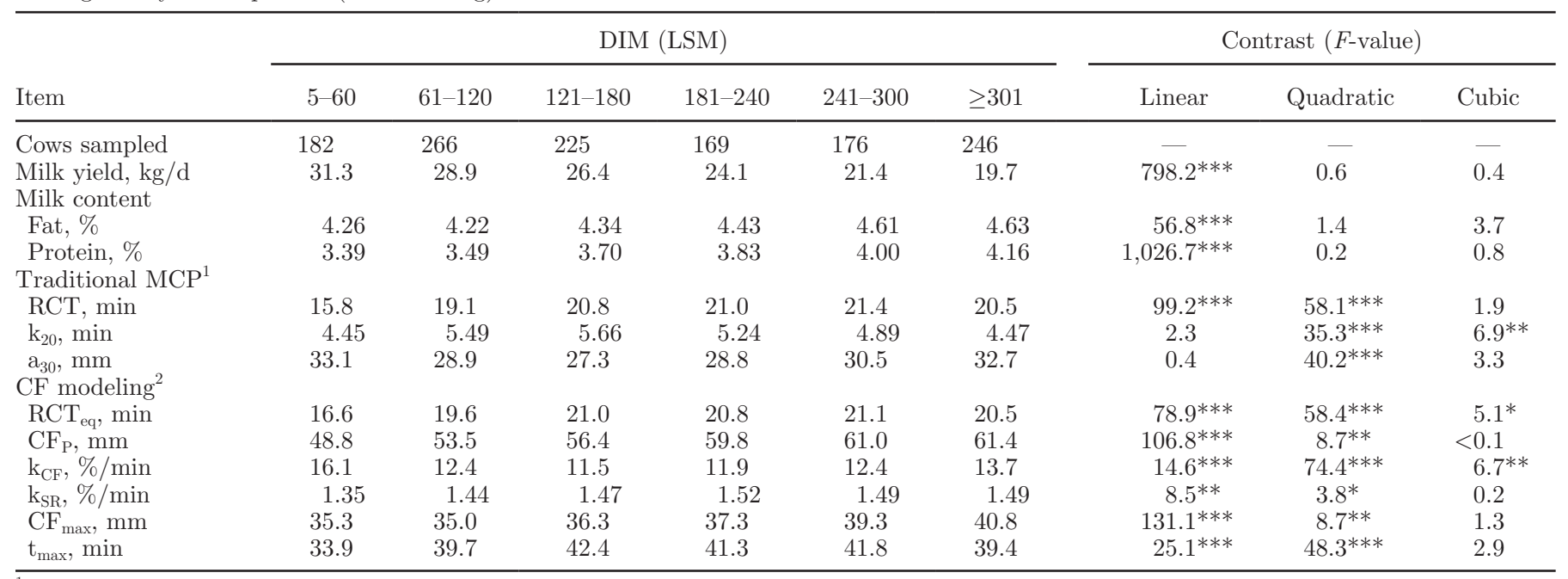

${ }^{1} \mathrm{RCT}=$ rennet coagulation time; $\mathrm{k}_{20}=$ time interval between $\mathrm{RCT}$ and a measured amplitude of oscillation of $20 \mathrm{~mm}$ (i.e., curd-firming rate); $\mathrm{a}_{30}=$ amplitude of oscillation (representing the final curd firmness) recorded 30 min after rennet addition.

${ }^{2} \mathrm{RCT}_{\mathrm{eq}}=\mathrm{RCT}$ estimated by $\mathrm{CF}$ model; $\mathrm{CF}_{\mathrm{P}}=$ asymptotic potential $\mathrm{CF}$ at infinite time; $\mathrm{k}_{\mathrm{CF}}=$ instant rate constant of curd firming; $\mathrm{k}_{\mathrm{SR}}=$ instant rate constant for syneresis; $\mathrm{CF}_{\max }=$ maximum curd firmness; $\mathrm{t}_{\max }=$ time to maximum curd firmness.

${ }^{*} P<0.05 ;{ }^{* *} P<0.01 ; * * P<0.001$. 
Table 7. Pearson product-moment correlations between curd firming modeling parameters and traditional milk coagulation properties (MCP; $\mathrm{n}=1,163)$

\begin{tabular}{|c|c|c|c|c|c|c|c|c|}
\hline & \multicolumn{2}{|c|}{ Traditional $\mathrm{MCP}^{1}$} & \multicolumn{6}{|c|}{$\mathrm{CF}_{\mathrm{t}}$ modeling ${ }^{2}$} \\
\hline & $\mathrm{k}_{20}$ & $\mathrm{a}_{30}$ & $\mathrm{RCT}_{\mathrm{eq}}$ & $\mathrm{CF}_{\mathrm{P}}$ & $\mathrm{k}_{\mathrm{CF}}$ & $\mathrm{k}_{\mathrm{SR}}$ & $\mathrm{CF}_{\max }$ & $t_{\max }$ \\
\hline $\mathrm{RCT}, \min$ & 0.52 & -0.78 & 0.98 & 0.35 & -0.71 & NS & -0.20 & 0.88 \\
\hline $\mathrm{k}_{20}, \min$ & & -0.72 & 0.50 & -0.10 & -0.54 & -0.10 & -0.61 & 0.58 \\
\hline $\mathrm{a}_{30}, \mathrm{~mm}$ & & & -0.76 & NS & 0.59 & 0.07 & 0.55 & -0.73 \\
\hline \multicolumn{9}{|l|}{$\mathrm{CF}_{\mathrm{t}}$ modeling } \\
\hline $\mathrm{k}_{\mathrm{CF}}, \% / \min$ & & & & & & -0.07 & 0.15 & -0.75 \\
\hline $\mathrm{k}_{\mathrm{SR}}, \% / \mathrm{min}$ & & & & & & & -0.15 & -0.27 \\
\hline $\mathrm{CF}_{\max }, \mathrm{mm}$ & & & & & & & & NS \\
\hline
\end{tabular}

${ }^{1} \mathrm{RCT}=$ rennet coagulation time; $\mathrm{k}_{20}=$ time interval between $\mathrm{RCT}$ and a measured amplitude of oscillation of $20 \mathrm{~mm}$ (i.e., curd-firming rate); $\mathrm{a}_{30}=$ amplitude of oscillation (representing the final curd firmness) recorded 30 min after rennet addition.

${ }^{2} \mathrm{RCT}_{\mathrm{eq}}=\mathrm{RCT}$ estimated by $\mathrm{CF}$ model; $\mathrm{CF}_{\mathrm{P}}=$ asymptotic potential $\mathrm{CF}$ at infinite time; $\mathrm{k}_{\mathrm{CF}}=$ instant rate constant of curd firming; $\mathrm{k}_{\mathrm{SR}}=$ instant rate constant for syneresis; $\mathrm{CF}_{\max }=$ maximum curd firmness; $\mathrm{t}_{\max }=$ time to maximum curd firmness.

\section{Relationships Among Traditional MCP and Curd-Firming Parameters}

Pearson product-moment correlations among the considered traits (traditional $\mathrm{MCP}$ and $\mathrm{CF}_{\mathrm{t}}$ modeling) are summarized in Table 7. Among the traditional MCP measures, we found high correlations $(>0.50)$, whereas for $\mathrm{CF}_{\mathrm{t}}$ modeling parameters, only 1 of 6 correlation coefficients was greater than $0.50(-0.70$ between $\mathrm{RCT}_{\text {eq }}$ and $\mathrm{k}_{\mathrm{CF}}$ ). The 2 traits calculated from the $\mathrm{CF}_{\mathrm{t}}$ equations were not correlated: $\mathrm{CF}_{\max }$ was not highly correlated with any of the $4 \mathrm{CF}_{\mathrm{t}}$ parameters, whereas $\mathrm{t}_{\max }$ was highly correlated with $\mathrm{RCT}_{\text {eq }}(0.87)$ and $\mathrm{k}_{\mathrm{CF}}(-0.75)$.

Finally, considering the relationships between traditional $\mathrm{MCP}$ and $\mathrm{CF}_{\mathrm{t}}$ modeling parameters and derived traits, $\mathrm{RCT}_{\mathrm{eq}}$ was almost identical to traditional $\mathrm{RCT}$ (0.98) and highly correlated with the other $2 \mathrm{MCP}$ (Table 7). Traits $\mathrm{CF}_{\mathrm{P}}$ and $\mathrm{k}_{\mathrm{SR}}$ were not highly correlated with traditional $\mathrm{MCP}$, whereas $\mathrm{k}_{\mathrm{CF}}, \mathrm{CF}_{\max }$, and $\mathrm{t}_{\max }$ were all highly correlated $(-0.54$ to 0.88$)$ with traditional MCP, with the only exception being $\mathrm{CF}_{\max }$ with RCT.

\section{DISCUSSION}

\section{Modeling Coagulation, CF, and Syneresis}

The major limitations of traditional MCP include (1) the existence of NC samples (Ikonen et al., 1999); (2) the high proportion of samples for which $\mathrm{k}_{20}$ cannot be measured (Cipolat-Gotet et al., 2012); and (3) the strong dependence of $\mathrm{a}_{30}$ on RCT, both phenotypically and genetically (Ikonen et al., 2004). Among the traditional $\mathrm{MCP}, \mathrm{k}_{20}$ is very important for the dairy industry, as it indicates the optimal moment for curd cutting (Bynum and Olson, 1982). The relevance of this problem has increased in recent years due to the growing worldwide dominance of the Holstein-Friesian breed, which is characterized by a higher proportion of $\mathrm{NC}$ and late-coagulating milk samples compared with other dairy breeds (Bittante et al., 2012).

In a previous study, prolonging the test duration and modeling point observations (one every $15 \mathrm{~s}$ ) for each individual sample according to a 4-parameter $\mathrm{CF}_{\mathrm{t}}$ model yielded good results with ovine milk (Bittante et al., 2014b; Vacca et al., 2015). In bovine species, the only previous application of this strategy to a large data set was the comparison of Holsteins and first- or secondgeneration crossbred cows using a 3-parameter model and a 60-min interval (Malchiodi et al., 2014). The current study demonstrated that samples traditionally classified as NC (not coagulating within $30 \mathrm{~min}$ ) could be better defined as late-coagulating samples because they almost all coagulated after 30 min. Moreover, application of the $\mathrm{CF}_{\mathrm{t}}$ model to individual samples yielded a very accurate description of the pattern observed in the large majority of milk samples. The few samples that coagulated very late $(6.9 \%)$ presented some problems because there was only a short interval from gelation to the end of the $\mathrm{CF}_{\mathrm{t}}$ measurements, and the few available point observations with $\mathrm{CF}$ values greater than zero did not allow us to obtain sound estimations of the model parameters (with the exception of $\mathrm{RCT}_{\mathrm{eq}}$ ). For these observations, the estimated $\mathrm{CF}_{\mathrm{P}}$ was often very high (Figure 1), whereas the 2 instant rate constants were very low.

The effect of using information from all points rather than single points is evident when we compare the traditionally measured RCT with that obtained from the model $\left(\mathrm{RCT}_{\text {eq }}\right)$. As shown in Table 2, the residual root mean square error (RMSE) of the modeled value was 
$16 \%$ smaller than that of the traditionally measured $\mathrm{RCT}$, and the corresponding residual variance was $30 \%$ lower. This explains the tendency for different sources of variation to be more significant when observed for $\mathrm{RCT}_{\mathrm{eq}}$ than for RCT. It is not feasible to directly compare the other traits, but it is worth noting that the residual RMSE of the traditional $\mathrm{a}_{30}$ was $35 \%$ of its average value, whereas that of $\mathrm{CF}_{\mathrm{P}}$ was $24 \%$ of its average (despite the latter being an asymptotic parameter at infinite time) and that of $\mathrm{CF}_{\max }$ was only $15 \%$ of its average. Comparison of the rate traits revealed that the residual RMSE was $47 \%$ for the traditional $k_{20}$ and $39 \%$ for $\mathrm{k}_{\mathrm{CF}}$; for $\mathrm{k}_{\mathrm{SR}}$, the residual RMSE was $32 \%$ of the average value; and for $t_{\max }$, the residual RMSE was only $26 \%$. In general, the equation parameters and the derived traits $\left(\mathrm{CF}_{\max }\right.$ and $\left.\mathrm{t}_{\max }\right)$ tended to present $F$-statistics and significance levels greater than those of the traditional MCP (Table 2). Moreover, the herd variances of the equation parameters appeared to represent greater proportions of the total variances than seen for the MCP, perhaps reflecting smaller residual variances.

The high correlation among the 3 traditional MCP traits found in the present study (Table 7) confirms previous studies (Bittante et al., 2012) and highlights the limit of such parameters in interpreting the milk coagulation pattern. Therefore, their application at the industry level is questionable. The $\mathrm{CF}_{\mathrm{t}}$ parameters, in contrast, showed a much larger level of independence among themselves, and thus it seems easier to characterize each one, also in relation to a possible application at the industry level. New research on this topic is needed. Nevertheless, it is worth noting that the $\mathrm{CF}_{\mathrm{t}}$ parameters and derived traits describing the late part of the $\mathrm{CF}_{\mathrm{t}}$ curve $\left(\mathrm{CF}_{\mathrm{P}}, \mathrm{k}_{\mathrm{SR}}\right.$, and $\left.\mathrm{CF}_{\max }\right)$ are strictly genetically correlated to cheese-yield traits than the traditional MCP (A. Cecchinato and G. Bittante, unpublished data).

\section{Effect of the Dairy Farming System on CF Modeling}

Trento Province, which is located in the northeastern Italian Alps, includes a variety of dairy farming systems, ranging from a very traditional Alpine system, in which tied animals are fed hay and some concentrates and moved to highland pastures for summer transhumance, to very modern, intensive systems based on loose housing, milking parlors, and year-round feeding that includes TMR. Compared with other mountain dairy systems, those in Trento Province are unusual in that the pasture is only really used for summer transhumance, and silage is seldom used. This is because $\sim 50 \%$ of the milk produced in the area is destined for the production of the Trentingrana cheese [or
Grana del Trentino, a Protected Designation of Origin (PDO) hard, long-ripened cheese typical of the area], whereas another $25 \%$ of the milk is destined for production of other typical local cheeses (Merz, 2011). As seen for Parmigiano-Reggiano, the production norms for Trentingrana cheese forbid the use of ensiled forage and limit the use of fresh forage to feed lactating cows. The purpose of this restriction is to reduce contamination of milk with spores of Clostridia spp. (Stadhouders and Spoelstra, 1990), which is responsible for the late swelling of cheeses during the 2-yr ripening period (Formigoni and Fustini, 2011). The higher costs of these mountain farming systems are offset by the higher prices, approximately $+50 \%$ ) paid by cooperative dairies that produce Trentingrana cheese (Sturaro et al., 2013). The technological properties of milk are particularly important for the production of PDO traditional cheeses (Martin et al., 2003; Bertoni et al., 2005; Calamari et al., 2005). In fact, the strict definitions of the processing techniques and conditions that may be used to produce PDO cheese do not allow the use of modern technology to overcome inadequacies in the processed milk; thus, top-quality milk (at least from the technological point of view) must be guaranteed (Saccà et al., 2003; Summer et al., 2003; Malacarne et al., 2006). As the technological properties of milk affect the yield, quality, sensory properties, grading, and price of Trentingrana cheese (Bittante et al., 2011a,b), the cooperative dairies systematically evaluate MCP and include them in the milk payment system.

The large differences observed in daily milk production traits, components, and quality favored the modern dairy systems over the traditional system (Table 3 ) and did not seem to be affected by genetic factors. The 85 farms sampled in the present study all had cows of the same breed (Brown Swiss) and used only AI with semen of young and proven Brown Swiss bulls supplied by the Trento Provincial Breeders Federation. Preliminary analysis demonstrated that sire selection decisions were not related to herd management (data not shown). Thus, consistent with the results of 2 large surveys carried out in the same area (Sturaro et al., $2009,2013)$, the production differences observed herein reflect between-system differences in structural, management, and feeding conditions.

Few differences in production and milk quality traits were found in favor of modern dairy systems that fed TMR compared with those that separately provided roughage and concentrates, and only a trivial effect was attributed to the source of moisture in the TMR (i.e., silage vs. water). The traditional MCP (RCT, $\mathrm{k}_{20}$, and $a_{30}$ ) were not greatly affected by dairy farming system. The existing literature lacks large surveys on the effect of different dairy systems, and the published results 
comparing different feeding strategies have reported minor and sometimes contradictory effects. Consistent with the results of the present study, Grandison et al. (1985) studied cheese-making using the milk of cows from different farms and fed with different types and proportions of forage. Those authors found favorable relationships between increased dietary fiber and milk coagulation and syneresis times and unfavorable relationships with diet energy and CP contents, but found no relationship with coagulum strength. In contrast, especially when the roughage was of low quality and the concentrate proportion was very low, Macheboeuf et al. (1993), Kreuzer et al. (1996), and Tyrisevä et al. (2004) found that increasing the concentrate while maintaining similar $\mathrm{CP}$ content had a favorable effect on RCT but no effect on CF. Malossini et al. (1996) studied average-producing cows and found that increasing their total energy allowance by increasing the supply of concentrates had favorable effects on $\mathrm{CF}$ and the proportion of samples exhibiting a $\mathrm{k}_{20}$ within $30 \mathrm{~min}$, but not on RCT. The same authors found that MCP were unaltered by a change in the forage:concentrate ratio when the total energy allowance and $\mathrm{CP}$ content were kept consistent. Butler et al. (2010) studied intensive milk production from Holstein cows and found that the energy density of the diet did not affect MCP at the beginning of lactation. In the studies cited above, the effect of feed availability and quality on milk acidity and protein and casein contents was small and often not significant.

Herd was found to have significant effects in some studies (Mariani et al., 1992; Cecchinato, 2013) but not others (Malchiodi et al., 2014). The relative scarcity of such reports may reflect (at least in part) the modest repeatability of traditional MCP measures (Caroli et al., 1990; Tyrisevä et al., 2003). In the present study, the $\mathrm{CF}_{\mathrm{t}}$ modeling of individual samples yielded a clearer picture of the effects of various dairy systems on the studied parameters. Although we confirmed the advantage of TMR within modern dairy farms in terms of curd-firming rate, $\mathrm{RCT}_{\text {eq }}$ (unlike traditional $\mathrm{RCT}$ ) reached statistical significance in favor of milk from traditional farms. Moreover, our $\mathrm{CF}_{\mathrm{t}}$ modeling yielded new information, particularly regarding the syneresis process. We report herein that milk from cows maintained under the traditional dairy system was characterized by a faster syneresis, as expressed by the $\mathrm{k}_{\mathrm{SR}}$ instant rate constant; this explains the earlier achievement $\left(t_{\max }\right)$ and lower value $\left(\mathrm{CF}_{\max }\right)$ of the maximum CF (Table 3). The $t_{\max }$ was also reached earlier within the modern dairy systems that used TMR.

Knowledge of the 4 parameters allowed us to fully model patterns of coagulation, curd firming, and syneresis, and to test their contributions to the differences observed among the different dairy systems. As shown in Figure 2, between-sample differences were not very evident in the first part of the $\mathrm{CF}_{\mathrm{t}}$ curve, which was dominated by coagulation time and curd firming rate; instead, they became more evident approaching $30 \mathrm{~min}$ from rennet addition, when syneresis began to affect the curve shape. This finding shows that traditional $\mathrm{MCP}$ recorded over $30 \mathrm{~min}$ cannot fully represent the cheese-making process.

\section{Effect of Season on CF Modeling}

The small difference in daily milk yield in favor of the summer season was accompanied by lower milk fat and protein contents. Notably, the feeding regimen was consistent year-round for all of the considered dairy systems; the only exception was summer transhumance, which was excluded from sampling in the present study. Moreover, the effect induced by seasonality of calving was removed by including DIM in the statistical model.

In previous studies, seasonal effects were included in statistical models aimed at examining traditional MCP at the population level, but season has not been discussed in detail (Tyrisevä et al., 2003). Malacarne et al. (2005) analyzed the MCP of samples from Friesian and Brown Swiss cows whose milk was destined for Parmigiano-Reggiano cheese production. The authors observed a significant effect of season and an interaction between season and breed, and interpreted these findings in relation to differences in the environments and calving distributions of the 2 breeds. Thus, unlike the present study, the previous findings on the effect of season were partially confounded by differences in dairy system and stage of lactation.

The 3 traditional MCP ( $\mathrm{RCT}, \mathrm{k}_{20}$, and $\mathrm{a}_{30}$ ) were affected by season only in terms of coagulation time, whereas the 4 model parameters $\left(\mathrm{RCT}, \mathrm{CF}_{\mathrm{P}}, \mathrm{k}_{\mathrm{CF}}\right.$, and $\left.\mathrm{k}_{\mathrm{SR}}\right)$ and the 2 derived traits $\left(\mathrm{CF}_{\max }\right.$ and $\left.\mathrm{t}_{\max }\right)$ were all significantly affected by season (Table 4). Representation of the equations using the LSM of the $4 \mathrm{CF}_{\mathrm{t}}$ model parameters (Figure 3) showed significant differences in the patterns observed for milk samples produced during summer versus winter. These differences became evident beyond $30 \mathrm{~min}$ from rennet addition due to the effects of $\mathrm{CF}_{\mathrm{P}}$ and $\mathrm{k}_{\mathrm{SR}}$. It is worth noting that the most important cheese produced in the area, the Trentingrana hard cheese, shows significant effects of season on the incidence of first-quality wheels (Bittante et al., 2011a) and on sensorial properties (Bittante et al., 2011b), even though the feeding regimen of farms providing milk to the province's dairy cooperative is constant during the year with almost no use of pasture, green fodder, or silages (Sturaro et al., 2013). 


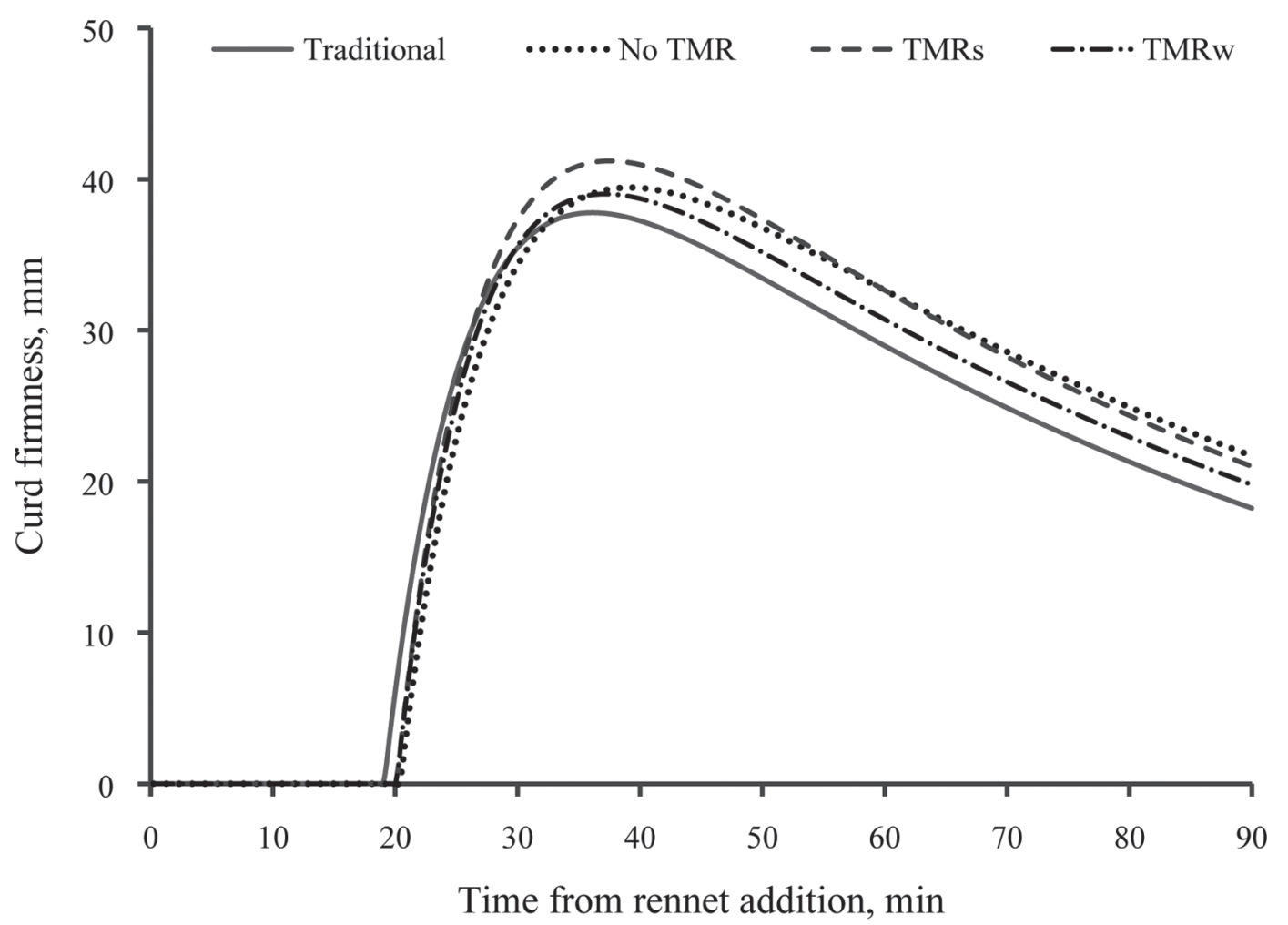

Figure 2. Effect of dairy farming system on modeling of milk coagulation, curd firming, and syneresis. Traditional = traditional system with

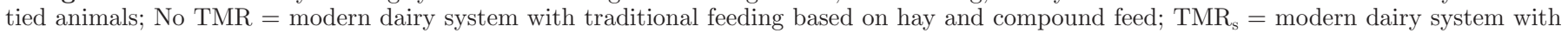
TMR that included silage; $\mathrm{TMR}_{\mathrm{w}}=$ modern dairy system with silage-free TMR (water added for moisture).

\section{Effect of Parity on CF Modeling}

Parity has often been considered in statistical analyses of traditional MCP surveys but it has rarely reached statistical significance. For example, Macheboeuf et al. (1993) found no difference in MCP between cows in their first and second lactations during winter (indoor feeding), but observed better MCP for second-parity cows pastured during spring. Tyrisevä et al. (2003) found better MCP for first-lactation cows than for those in subsequent lactations. Cecchinato (2013) performed survival analysis of an RCT data set with $\mathrm{NC}$ data and found that the significance of parity was affected by the statistical procedure used. Using a 3 -parameter model of milk from purebred Holsteins and crossbred cows from dairy farms that produce milk for Parmigiano-Reggiano cheese, Malchiodi et al. (2014) found that $\mathrm{CF}_{\mathrm{P}}$ was higher during the second lactation than during the third or further lactations, whereas parity was not significant for the traditional MCP. In the present study, beyond the expected effects on milk yield and composition (Table 5), parity had no effect on the 3 traditional MCP, but significantly affected 5 of 6 parameters and derived traits yielded by $\mathrm{CF}_{\mathrm{t}}$ modeling. Milk samples from first-lactation cows were characterized by slower $\mathrm{k}_{\mathrm{SR}}$ (and consequently a higher and delayed $\mathrm{CF}_{\max }$ ) and $\mathrm{k}_{\mathrm{CF}}$ values compared with milk from subsequent lactations. Moreover, some significant differences were observed among later lactations. Representation of the equations based on the LSM of the model parameters (Figure 4) clearly showed that the combined parameters could be used to differentiate the samples of the oldest cows ( $\geq 4$ lactations) from those of the youngest (first lactation), particularly in the latter half of the $\mathrm{CF}_{\mathrm{t}}$ curves.

\section{Effect of Lactation Stage on CF Modeling}

Beyond the well-known effects of lactation stage on milk production and quality traits (Table 6), the present survey confirmed the relevance of DIM to the traditional MCP. For example, RCT increased (worsened) during the first part of lactation and stabilized thereafter (showing both linear and quadratic trends), confirming the previous reports of Macheboeuf et al. (1993), Kreuzer et al. (1996), Tyrisevä et al. (2003, 2004), Jõudu et al. (2007), and especially Malchiodi et al. (2014). Both $\mathrm{k}_{20}$ and $\mathrm{a}_{30}$ were characterized by more unfavorable values (higher and lower, respectively) at mid lactation (showing mainly quadratic trends). The 


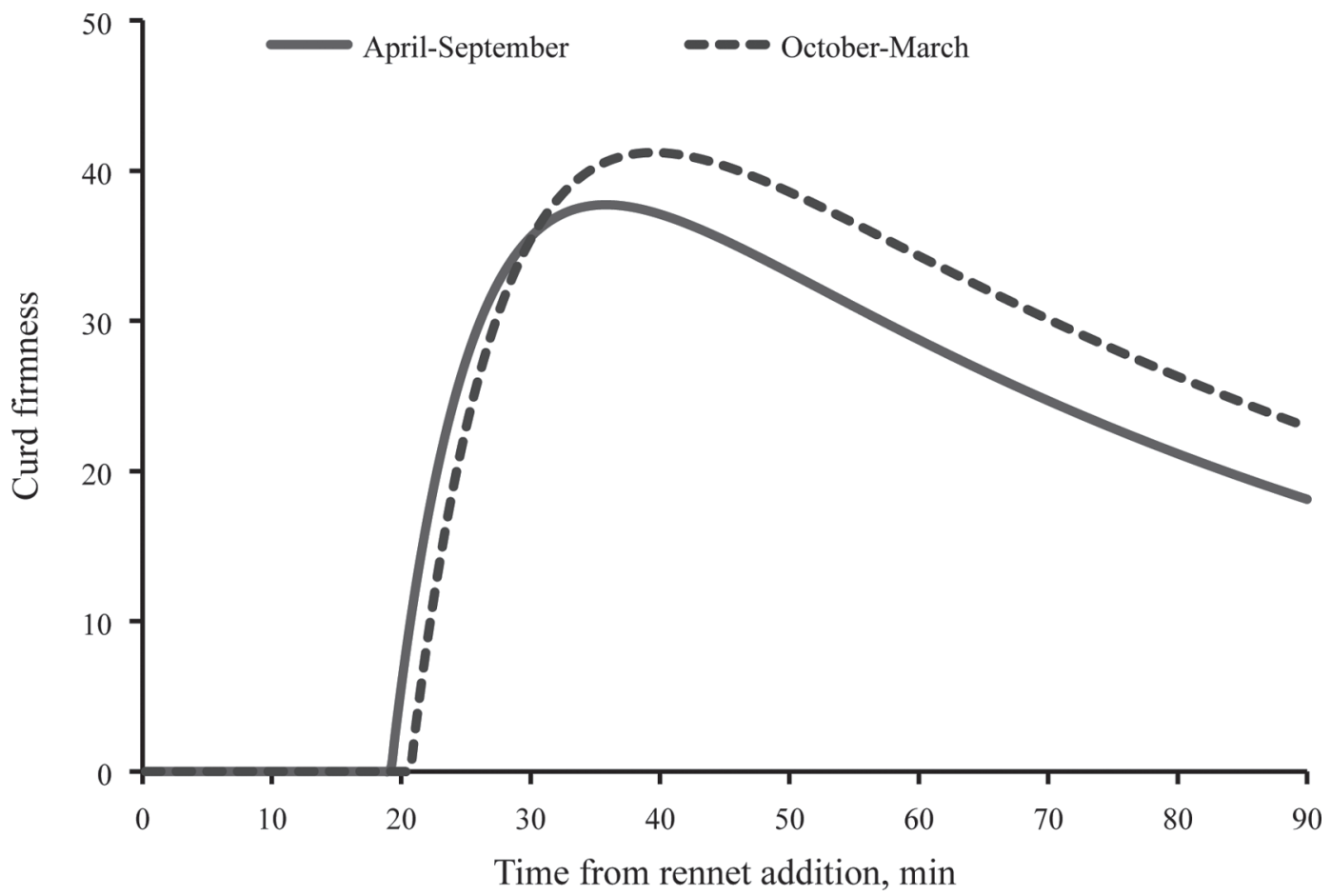

Figure 3. Effect of season on modeling milk coagulation, curd firming, and syneresis.

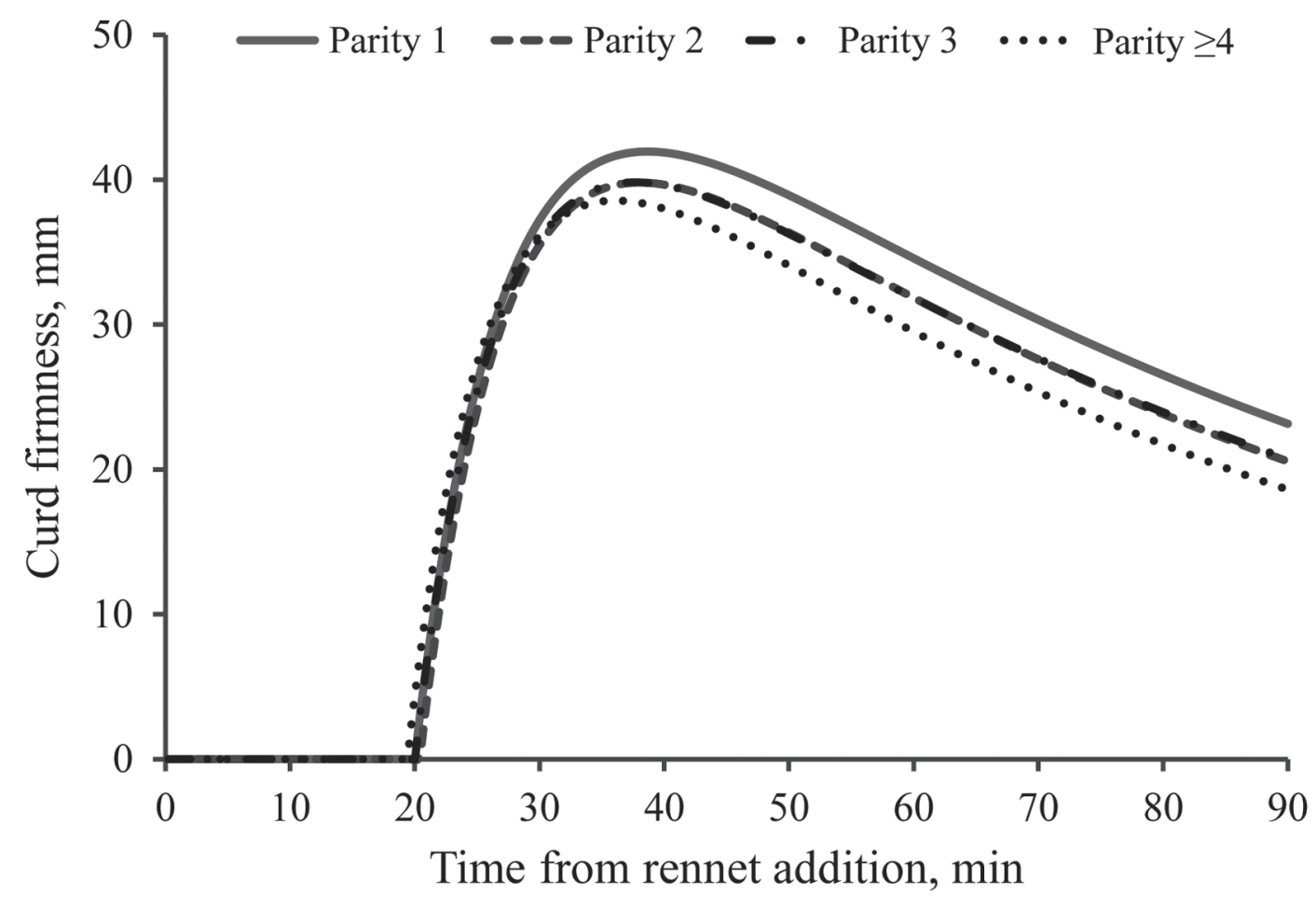

Figure 4. Effect of parity of cow on modeling of milk coagulation, curd firming, and syneresis. 


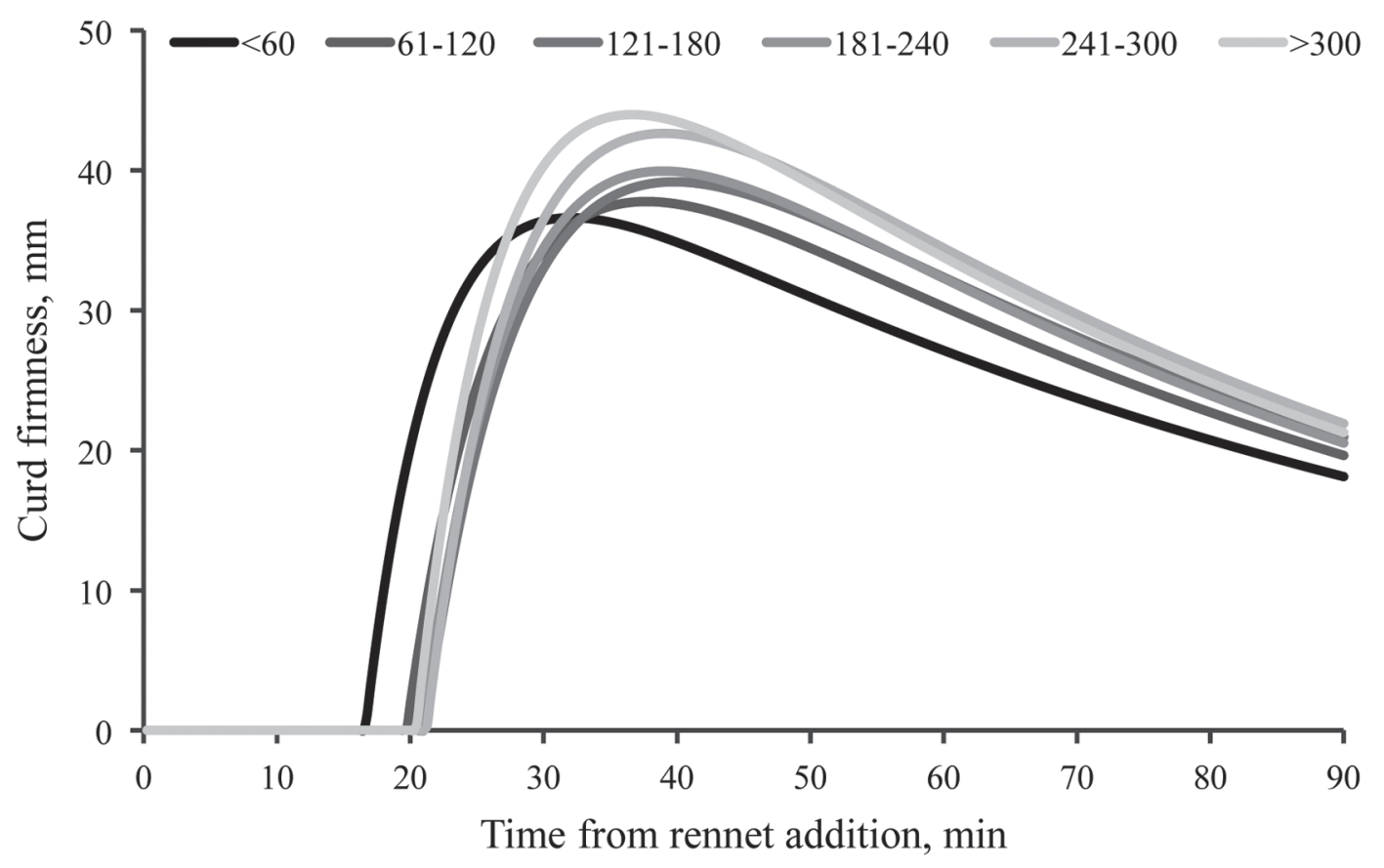

Figure 5. Effect of DIM of cow on modeling of milk coagulation, curd firming, and syneresis.

pattern observed for $\mathrm{a}_{30}$ was very similar to that previously observed by Tyrisevä et al. $(2003,2004)$ and Jõudu et al. (2007). In contrast, Kreuzer et al. (1996) observed better $\mathrm{CF}$ at the end of lactation than at the beginning, and Malchiodi et al. (2014) reported the opposite pattern for $\mathrm{k}_{20}$ and $\mathrm{a}_{30}$. However, the latter authors applied a 3-parameter $\mathrm{CF}_{\mathrm{t}}$ model and obtained lactation-related patterns very similar to the current results for RCT and $\mathrm{k}_{\mathrm{CF}}$, and relatively constant values for $\mathrm{CF}_{\mathrm{P}}$. Notably, Jõudu et al. (2007), Cecchinato (2013), and Malchiodi et al. (2014) all observed rapid increases (after calving) followed by decreases (at the end of lactation) in the incidence of $\mathrm{NC}$ samples (all studies) and samples without a measure of $k_{20}$ (Jõudu et al., 2007). Cecchinato (2013) did not evaluate $k_{20}$, whereas Malchiodi et al. (2014) adopted $\mathrm{CF}_{\mathrm{t}}$ modeling, which allowed them to estimate $\mathrm{k}_{20}$ for all coagulating samples. In the present study, the incidence of both categories of samples was negligible because we prolonged the test length to $90 \mathrm{~min}$ and used 4-parameter modeling.

With respect to the $\mathrm{CF}_{\mathrm{t}}$ model parameters and the derived traits examined herein, $\mathrm{RCT}_{\mathrm{eq}}, \mathrm{CF}_{\mathrm{P}}$, and $\mathrm{k}_{\mathrm{SR}}$ tended to increase sharply at the beginning of lactation and become approximately constant afterward. In contrast, $\mathrm{CF}_{\max }$ tended to remain stable through mid lactation and increase toward the end of lactation, whereas and $\mathrm{k}_{\mathrm{CF}}$ and $\mathrm{t}_{\max }$ tended to reach their minimum and maximum greatest values, respectively, at mid lactation. Our graphic representation of the av- erage $\mathrm{CF}_{\mathrm{t}}$ equations (Figure 5) shows that (unlike our findings for dairy system, season, and parity) lactation stage heavily affected the first part of the curve, especially when milk samples from fresh cows $(<60$ DIM) were compared with samples taken after the peak of lactation. Thereafter, progressive increases in $\mathrm{CF}_{\mathrm{P}}$ and $\mathrm{CF}_{\max }$ were particularly evident.

\section{CONCLUSIONS}

The present study offers new insights into the complex processes of coagulation, curd firming, and syneresis of bovine milk. Our results show for the first time that prolonging the observation time after rennet addition is a crucial adjustment, and that modeling all point observations recorded for each milk sample to obtain individual 4-parameter equations is an efficient strategy for exploiting all available information and condensing it into a few easily interpretable parameters. We report new information obtained from the declining parts of the $\mathrm{CF}_{\mathrm{t}}$ curves for the combined $\mathrm{k}_{\mathrm{SR}}$, $\mathrm{CF}_{\max }$, and $\mathrm{t}_{\max }$ traits, and we suggest that this avenue warrants further study in terms of cheese-making. Furthermore, we show that the data on coagulation time, curd firming, and curd firmness seem to be characterized by better repeatability and lesser dependency on the duration of the lacto-dynamographic test when derived from all-point sample modeling, compared with the results obtained from the traditional single-point method. This new tool allowed us to better study the 
effects of dairy system, season, herd (within a given dairy system or season), parity, and lactation stage on the processes of coagulation, curd firming, and syneresis. The milk samples from cows reared in traditional mountain farms showed better technological traits than milk samples from cows of the same breed and genetic level kept in more modern, intensive herds. Among the latter, we observed improvements in the curd firming rate and time to maximum $\mathrm{CF}$ in farms that adopted TMR compared with those separately administering roughage and concentrates. Dairy system, season, and parity had particularly strong effects, especially on milk syneresis (and thus the declining part of the $\mathrm{CF}_{t}$ curve), whereas stage of lactation had stronger effects on coagulation time and initial curd firming of samples. In the future, the strategy of prolonging the test duration and individually modeling the milk technological properties could be used to examine other important sources of variation, especially genetic sources, by (for example) performing breed comparisons and examining within-breed heritability.

\section{ACKNOWLEDGMENTS}

The authors thank the Autonomous Province of Trento (Italy) for funding the project (Cowplus project) and the RISIB SMUPR project n. 4145 for the availability of the instruments of the NIRS-Food laboratory (Department of Agronomy, Food, Natural Resources, Animals and Environment (DAFNAE), Legnaro, Italy). The authors gratefully acknowledge Claudio Valorz and technicians of FPAT (Federazione Provinciale Allevatori Trento) for their collaboration.

\section{REFERENCES}

Ali, A. K. A., and G. E. Shook. 1980. An optimum transformation for somatic cell concentration in milk. J. Dairy Sci. 63:487-490.

Annibaldi, S., F. Ferri, and R. Morra. 1977. Nuovi orientamenti nella valutazione tecnica del latte: Tipizzazione lattodinamografica. Sci. Tecn. Latt. Cas. 28:115-126.

Bertoni, G., L. Calamari, M. G. Maianti, and B. Battistotti. 2005. Milk for Protected Denomination of Origin (PDO) cheeses: I. The main required features. Pages 217-228 in Indicators of Milk and Beef Quality. J. F. Hocquette and S. Gigli, ed. EAAP Publication 112. Wageningen Academic Publishers, Wageningen, the Netherlands.

Bittante, G. 2011. Modeling rennet coagulation time and curd firmness of milk. J. Dairy Sci. 94:5821-5832.

Bittante, G., A. Cecchinato, N. Cologna, M. Penasa, F. Tiezzi, and M. De Marchi. 2011a. Factors affecting the incidence of first-quality wheels of Trentingrana cheese. J. Dairy Sci. 94:3700-3707.

Bittante, G., C. Cipolat-Gotet, and A. Cecchinato. 2013a. Genetic analysis of different measures of cheese-yield and nutrients recovery from individual bovine milk and their genetic relationships with milk yield and composition. J. Dairy Sci. 96:7966-7979.

Bittante, G., N. Cologna, A. Cecchinato, M. De Marchi, M. Penasa, F. Tiezzi, I. Endrizzi, and F. Gasperi. 2011b. Monitoring of sensory attributes used in the quality payment system of Trentingrana cheese. J. Dairy Sci. 94:5699-5709.
Bittante, G., B. Contiero, and A. Cecchinato. 2013b. Prolonged observation and modelling of milk coagulation, curd firming, and syneresis. Int. Dairy J. 29:115-123.

Bittante, G., A. Ferragina, C. Cipolat-Gotet, and A. Cecchinato. 2014a. Comparison between genetic parameters of cheese yield and nutrient recovery or whey loss traits measured from individual model cheese-making methods or predicted from unprocessed bovine milk samples using Fourier-transform infrared spectroscopy. J. Dairy Sci. 97:6560-6572. http://dx.doi.org/10.3168/jds.20148309.

Bittante, G., E. Pellattiero, F. Malchiodi, C. Cipolat-Gotet, M. Pazzola, G. M. Vacca, S. Schiavon, and A. Cecchinato. 2014b. Quality traits and modeling of coagulation, curd firming, and syneresis of sheep milk of Alpine breeds fed diets supplemented with rumenprotected conjugated fatty acid. J. Dairy Sci. 97:4018-4028.

Bittante, G., M. Penasa, and A. Cecchinato. 2012. Invited review: Genetics and modeling of milk coagulation properties. J. Dairy Sci. 95:6843-6870.

Butler, S. T., M. A. de Feu, B. O'Brien, T. P. Guinee, and J. J. Murphy. 2010. Short communication: the effect of dry period duration and dietary energy density in early lactation on rennet gelation properties of milk. J. Dairy Sci. 93:524-528.

Bynum, D. G., and N. F. Olson. 1982. Influence of curd firmness at cutting on Cheddar cheese yield and recovery of milk constituents. J. Dairy Sci. 65:2281-2290.

Calamari, L., G. Bertoni, M. G. Maianti, and B. Battistotti. 2005. Milk for Protected Denomination of Origin (PDO) cheeses: II. The evaluation techniques of milk suitability. Pages 229-244 in Indicators of Milk and Beef Quality. J. F. Hocquette and S. Gigli ed. EAAP Publication 112. Wageningen Academic Publishers, Wageningen, the Netherlands.

Caroli, A., P. Bolla, G. Pagnacco, M. Rampilli, and L. Degano. 1990. Repeatability of milk clotting aptitude evaluated by lactodynamographic analysis. J. Dairy Res. 57:141-142.

Cecchinato, A. 2013. Survival analysis as a statistical methodology for analyzing factors that affect milk coagulation time in HolsteinFriesian and Brown Swiss cows. J. Dairy Sci. 96:5556-5564.

Cecchinato, A., C. Cipolat-Gotet, J. Casellas, M. Penasa, A. Rossoni, and G. Bittante. 2013. Genetic analysis of rennet coagulation time, curd-firming rate, and curd firmness assessed over an extended testing period using mechanical and near-infrared instruments. J. Dairy Sci. 96:50-62.

Cecchinato, A., M. Penasa, M. De Marchi, L. Gallo, G. Bittante, and P. Carnier. 2011. Genetic parameters of coagulation properties, milk yield, quality, and acidity estimated using coagulating and noncoagulating milk information in Brown Swiss and HolsteinFriesian cows. J. Dairy Sci. 94:4205-4213.

Cipolat-Gotet, C., A. Cecchinato, M. De Marchi, and G. Bittante. 2013. Factors affecting variation of different measures of cheese yield and milk nutrients recovery from individual model cheese manufacturing process. J. Dairy Sci. 96:7952-7965.

Cipolat-Gotet, C., A. Cecchinato, M. De Marchi, M. Penasa, and G. Bittante. 2012. Comparison between mechanical and near-infrared methods for assessing coagulation properties of bovine milk. J. Dairy Sci. 95:6806-6819.

Dejmek, P. 1987. Dynamic rheology of rennet curd. J. Dairy Sci. 70:1325-1330.

Douillard, R. 1973. Rheological analysis of curd formation. J. Texture Stud. 4:158-165.

Douillard, R. 1986. A kinetic-model for protease-induced milk clotting and curdling. Lebenson. Wiss. Technol. 19:202-207.

Formigoni, A., and M. Fustini. 2011. Regole per l'alimentazione delle bovine che producono latte per il Trentingrana. Pages 21-28 in Atti del Convegno La Filiera del Grana Trentino: Approcci Innovativi e Integrati alla Tecnologia e al Controllo Qualità, San Michele all'Adige, Italy. F. Gasperi and A. Cavazza, ed. Fondazione Edmund Mach, San Michele all'Adige (TN), Italy.

Gervais, A. 1983. Comparison of 2 models for fitting rennet-induced milk coagulation kinetics. J. Texture Stud. 14:47-59.

Grandison, A. S., M. Anderson, G. D. Ford, and L. Newell. 1985. Interrelationships between the diet fed to cow, composition and proper- 
ties of milk and composition and quality of Cheshire cheese from farmhouse manufaturers. J. Dairy Res. 52:587-593.

Ikonen, T., K. Ahlfors, R. Kempe, M. Ojala, and O. Ruottinen. 1999. Genetic parameters for the milk coagulation properties and prevalence of noncoagulating milk in Finnish dairy cows. J. Dairy Sci. 82:205-214.

Ikonen, T., S. Morri, A.-M. Tyrisevä, O. Ruottinen, and M. Ojala. 2004. Genetic and phenotypic correlations between milk coagulation properties, milk production traits, somatic cell count, casein content, and pH of milk. J. Dairy Sci. 87:458-467.

Jõudu, I., M. Henno, S. Värv, T. Kaart, and O. Kärt. 2007. Milk protein genotypes and milk coagulation properties of Estonian Native cattle. Agric. Food Sci. 16:222-231.

Kreuzer, M., A. M. von Siebenthal, A. Kaufmann, H. Ratzer, E. Jakob, and F. Sutter. 1996. Determination of the relative efficacy to enhance milk renneting properties of alterations in dietary energy, breed and stage of lactation. Milchwissenschaft 51:633-637.

Macheboeuf, D., J. B. Coulon, and P. D'Hour. 1993. Aptitude a la coagulation du lait de vache. Influence de la race, des variants genetiques des lactoproteines du lait, de l'alimentation et du numero de lactation. Prod. Anim. 6:333-344.

Malacarne, M., S. Fieni, F. Tosi, P. Franceschi, P. Formaggioni, and A. Summer. 2005. Seasonal variations of the rennet-coagulation properties of herd milks in Parmigiano-Reggiano cheese manufacture: comparison between Italian Friesian and Italian Brown cattle breeds. Ital. J. Anim. Sci. 4:242-244.

Malacarne, M., A. Summer, E. Fossa, P. Formaggioni, P. Franceschi, M. Pecorari, and P. Mariani. 2006. Composition, coagulation properties and Parmigiano-Reggiano cheese yield of Italian Brown and Italian Friesian herd milks. J. Dairy Res. 73:171-177.

Malchiodi, F., A. Cecchinato, M. Penasa, C. Cipolat-Gotet, and G. Bittante. 2014. Milk quality, coagulation properties, and curd firmness modeling of purebred Holsteins and first- and secondgeneration crossbred cows from Swedish Red, Montbéliarde, and Brown Swiss bulls. J. Dairy Sci. 97:4530-4541.

Malossini, F., S. Bovolenta, C. Piras, M. Dalla Rosa, and W. Ventura. 1996. Effect of diet and breed on milk composition and rennet coagulation properties. Ann. Zootech. 45:29-40.

Mariani, P., P. Bonatti, and S. Sandri. 1992. Contenuto di urea, pH, acidità titolabile e caratteristiche di coagulazione del latte di singoli allevamenti. L'industria del latte 28(3-4):3-17.

Martin, B., S. Buchin, and C. Hurtaud. 2003. Conditions de production du lait et qualities sensorielles des fromages. Prod. Anim. $16: 283-288$.

McMahon, D. J., and R. J. Brown. 1982. Evaluation of Formagraph for comparing rennet solutions. J. Dairy Sci. 65:1639-1642.

McMahon, D. J., G. H. Richardson, and R. J. Brown. 1984. Enzymic milk coagulation: role of equations involving coagulation time and curd firmness in describing coagulation. J. Dairy Sci. 67:11851193.

Merz, A. 2011. La realtà del Trentingrana. Pages $17-18$ in Atti del Convegno La Filiera del Grana Trentino: Approcci Innovativi e Integrati alla Tecnologia e al Controllo Qualità, San Michele all'Adige, Italy. F. Gasperi and A. Cavazza, ed. Fondazione Edmund Mach, San Michele all'Adige (TN), Italy.

O'Callaghan, D. J., and T. P. Guinee. 1996. Comparison of mathematical models applied to rennet coagulation of skim milks. J. Texture Stud. 26:607-633.

Saccà, E. S. Bovolenta, W. Ventura, and G. Gaiarin. 2003. Coagulation properties and Nostrano di Primiero cheese yield of milk from Brown grazing cows of different k-casein genotype. Ital. J. Anim. Sci. 2:284-286.

Stadhouders, J., and S. F. Spoelstra. 1990. Prevention of the contamination of raw milk by making good silage. Production of chymosin by microorganisms and its use for cheesemaking, detection and prevention of spore formers and cheese quality. Pages 24-31 in Document No. 251. International Dairy Federation, Brussels, Belgium.

Sturaro, E., G. Cocca, L. Gallo, M. Mrad, and M. Ramanzin. 2009. Livestock systems and farming styles in Eastern Italian Alps: An on-farm survey. Ital. J. Anim. Sci. 8:541-554.

Sturaro, E., E. Marchiori, G. Cocca, M. Penasa, M. Ramanzin, and G. Bittante. 2013. Dairy systems in mountainous areas: farm animal biodiversity, milk production and destination, and land use. Livest. Sci. 158:157-168.

Summer, A., P. Franceschi, A. Bollini, P. Formaggioni, F. Tosi, and P. Mariani. 2003. Seasonal variations of milk characteristics and cheesemaking losses in the manufacture of Parmigiano-Reggiano cheese. Vet. Res. Commun. 27:663-666.

Tyrisevä, A.-M., T. Ikonen, and M. Ojala. 2003. Repeatability estimates for milk coagulation traits and non-coagulation of milk in Finnish Ayrshire cows. J. Dairy Res. 70:91-98.

Tyrisevä, A.-M., T. Vahlsten, O. Ruottinen, and M. Ojala. 2004. Noncoagulation of milk in Finnish Ayrshire and Holstein-Friesian cows and effect of herds on milk coagulation ability. J. Dairy Sci. $87: 3958-3966$.

Vacca, G. M., M. Pazzola, M. L. Dettori, E. Pira, F. Malchiodi, C. Cipolat-Gotet, A. Cecchinato, and G. Bittante. 2015. Modeling of coagulation, curd firming and syneresis of milk from Sarda ewes. J. Dairy Sci. 98:2245-2259. http://dx.doi.org/10.3168/jds.20148902.

Zannoni, M., and S. Annibaldi. 1981. Standardization of the renneting ability of milk by Formagraph. Sci. Tecn. Latt. Cas. 32:79-94. 